\title{
Responses of developmental and physiological traits to manipulated incubation conditions in broiler embryos at hypoxic high altitude
}

\author{
Elif Babacanoğlu \\ Department of Animal Science, Faculty of Agriculture, University of Van Yuzuncu Yil, 65080 Van, Turkey \\ Correspondence: Elif Babacanoğlu (elifbabacanoglu@yyu.edu.tr)
}

Received: 16 May 2018 - Revised: 8 August 2018 - Accepted: 13 August 2018 - Published: 30 August 2018

\begin{abstract}
The effects of hypoxia at increased altitude levels on the cardio-respiratory development of broiler embryos are distinct in comparison with those at sea level. The aim of the study was to investigate the effects of high incubation temperature $(\mathrm{H})$ and oxygen supplementation $(\mathrm{O})$ during hypoxic high altitude (HA) on developmental and physiological traits of embryos and hatching performance of embryonated hatching eggs in broilers at different embryonic stages. A total of 1280 eggs obtained from broiler breeders laid at sea level were used. Eggshell quality characteristics were measured for 20 eggs. The rest of the 1260 eggs were divided into seven incubation condition (IC) groups (180 eggs per group) including a control group at $37.8^{\circ} \mathrm{C}$ and $21 \% \mathrm{O}_{2} ; \mathrm{O}$ groups, with daily $1 \mathrm{~h} 23.5 \% \mathrm{O}_{2}$ supplementation at $37.8^{\circ} \mathrm{C}$ as $\mathrm{O}_{0-11}, \mathrm{O}_{12-21}$, and $\mathrm{O}_{18-21} ; \mathrm{H}$ groups at $38.5^{\circ} \mathrm{C}$ high incubation temperature at $21 \% \mathrm{O}_{2}$ as $\mathrm{H}_{0-11}, \mathrm{H}_{12-21}$, and $\mathrm{H}_{18-21}$ from days 0 to 11,12 to 21 , and 18 to 21 of incubation, respectively. All groups were incubated in three different incubators at hypoxic HA. The effect of IC was determined on eggshell temperature, hatching performance, embryo development, right ventricular (RV) to total ventricular (TV) ratio, and blood parameters. The highest egg water loss and embryonic mortality and the lowest hatchability were in the $\mathrm{H}_{0-11}$ group, which depended on increased eggshell temperature during incubation. On day 18 of incubation, due to the decreased egg water loss in the $\mathrm{O}_{12-21}$ and $\mathrm{O}_{18-21}$ groups, there was an increase in hatchability in fertile eggs similar to the middle and late $\mathrm{H}$ groups. Towards the end of incubation, embryo/chick weights were not different and RV and TV weights increased in the treated groups, and the RV / TV ratio changed between 15 and $26 \%$. At hatching, yolk sac weight increased in $\mathrm{H}_{0-11}$ and $\mathrm{H}_{12-21}$ groups. The $\mathrm{O}$ groups had the lowest serum tri-iodothyronine $\left(\mathrm{T}_{3}\right)$ concentration as distinct from $\mathrm{H}$ groups. The serum thyroxine $\left(\mathrm{T}_{4}\right)$ concentration increased in the treated groups, dependent on sex of the embryo. Blood hemoglobin concentration of $\mathrm{O}$ groups decreased relative to other groups. The hematocrit value was the lowest in the $\mathrm{O}_{12-21}$ and highest in the $\mathrm{H}_{12-21}$ groups. The $\mathrm{H}$ and $\mathrm{O}$ treatments during pre-hatch hypoxic HA condition can be positively evaluated on physiological traits of embryos after half of incubation depended on the timing of the IC exposure to the hatching eggs obtained from broiler breeders at sea level.
\end{abstract}

\section{Introduction}

Intensive genetic selection for rapid growth in meat-type chickens has not occurred to the same extent for functions of heart and lungs (Lorenzoni and Ruiz-Feria, 2006). This leads to increased pulmonary hypertension or ascites susceptibility (Wideman et al., 2013; Khajali and Wideman, 2016) and reduced embryonic development and growth as high oxygen levels necessitate a high metabolic rate (Decuypere et al., 2005). Oxygen $\left(\mathrm{O}_{2}\right)$ provides continuity for metabolic functions and biochemical processes in embryonic cells as demanded by the development and growth of embryos ( $\mathrm{Si}-$ mon and Keith, 2008). Barometric pressure lowers when altitude increases, while the partial $\mathrm{O}_{2}$ pressure progressively falls, causing hypoxia, which represents a reduction and insufficiency of the $\mathrm{O}_{2}$ level in cells and tissues with failure to fulfil their normal function (Carreau et al., 2011). The reduced $\mathrm{O}_{2}$ availability at high altitude (HA) stimulates a 
higher respiration rate as the number of $\mathrm{O}_{2}$ molecules per breath is reduced. This phenomenon plays an important role in maintaining adequate $\mathrm{O}_{2}$ transfer to the blood (Monge and León-Velarde, 1991). Therefore, $\mathrm{O}_{2}$ level should be at $21 \%$ throughout the pre-hatch period in broilers at any altitude because cellular metabolic functions depend on the availability of $\mathrm{O}_{2}$.

Organ systems at different embryonic development periods have different "critical windows" (Burggren and Elmonoufy, 2017). Hypoxia occurring in early embryonic developmental stages may have different effects (Decuypere and Bruggeman, 2007) than at later stages of embryonic development. Under hypoxic conditions, organisms trigger changes in cellular and physiological levels to recover $\mathrm{O}_{2}$ homeostasis based on epigenetic changes (Perez-Perri et al., 2011). Epigenetic changes concluding with adaptation to hypoxia play a key role in the systemic homeostatic responses to hypoxia (Xia and Kung, 2009; Xia et al., 2009; Mutoh et al., 2012) which occurs by various physiological conditions (Semenza, 2003). Epigenetic adaptation to hypoxia by means of several practices during incubation may provide optimal embryonic development at HA (Babacanoğlu and Güler, 2018). At HA, these practices might be $\mathrm{O}_{2}$ supplementation to incubator and a higher incubation temperature because HA characterized by low atmospheric pressure resulting from air heat content causes the molecules to bounce off each other, and air temperature with increasing altitude decreases at a rate of approximately $6.5^{\circ} \mathrm{C}$ per $1000 \mathrm{~m}$. The results of recent studies on high incubation temperature indicated that embryos initially have an accelerated growth rate at a high incubation temperature. Eggshell temperature has been reported as $37.8^{\circ} \mathrm{C}$ for optimal embryonic development and hatching success at normoxia (Lourens et al., 2005, 2007; Molenaar et al., 2011). An eggshell temperature of $38.9^{\circ} \mathrm{C}$ from days 8 to 19 of incubation initially increased embryonic development, which was reflected in a high heat production, but a high eggshell temperature had a negative effect on embryonic development at the last stage of incubation (Lourens et al., 2007). Moreover, the embryos may be able to accomplish an accelerated growth rate by high $\mathrm{O}_{2}$ concentration at the end of incubation. For example, at the last stage of incubation, an increase in the $\mathrm{O}_{2}$ level $(25 \%)$ resulted in improved embryonic growth (Lourens et al., 2007). A deviation of $+0.7^{\circ} \mathrm{C}$ from the optimum incubation temperature or an $\mathrm{O}_{2}$ concentration of $23.5 \%$ can mitigate the negative effects of hypoxia caused by HA (1720 m) for optimum embryonic development (Babacanoğlu and Güler, 2018). Olkowski and Classen (1999) indicated that pulmonary hypertension or ascites susceptibility of broilers at sea level is associated with leading to cardiovascular failure due to rapid growth in broilers. This was observed at sea level (Scheele and Frankenhuis, 1989; Julian, 2000; Hassanzadeh et al., 2001) and has also been observed at HA (Albers and Frankenhuis, 1990). For this reason, this study was proposed to investigate the effects of high incubation temperature and $\mathrm{O}_{2}$ supplementation to hatching eggs obtained from broiler breeders at sea level $(2 \mathrm{~m})$ on developmental and physiological traits of embryo and hatching performance induced by hypoxia at a $1720 \mathrm{~m}$ altitude.

\section{Materials and methods}

All procedures were approved by Yuzuncu Yil University Animal Care and Use Committee (permit number 2016-04).

\subsection{Animal materials and experimental design}

A total of 1280 hatching eggs laid at sea level ( $2 \mathrm{~m}$ altitude) of Ross 308 broiler breeder at 45 weeks old were obtained from a local hatchery and stored for 7 days at $15^{\circ} \mathrm{C}$ and $75 \%$ relative humidity $(\mathrm{RH})$. Quality characteristics of 10 eggs randomly selected were measured. Eggshell conductance, pore concentration, and pore diameter were determined in a second set of 10 eggs. The rest of the 1260 eggs were numbered and divided into seven experimental groups (180 eggs per group at six setting trays: each replicate included 30 eggs) exposed to different incubation conditions (IC) as control: at $37.8^{\circ} \mathrm{C}$ and $21 \% \mathrm{O}_{2}$ throughout incubation; $\mathrm{O}_{2}$ supplementation $(\mathrm{O})$ groups: $\mathrm{O}_{0-11}$ : daily $1 \mathrm{~h} 23.5 \% \mathrm{O}_{2}$ supplementation from days 0 to 11 of incubation, $\mathrm{O}_{12-21}$ : daily $1 \mathrm{~h}$ $23.5 \% \mathrm{O}_{2}$ supplementation from days 12 to 21 of incubation, $\mathrm{O}_{18-21}$ : daily $1 \mathrm{~h} 23.5 \% \mathrm{O}_{2}$ supplementation from days 18 to 21 of incubation at $37.8^{\circ} \mathrm{C}$; high incubation temperature $(\mathrm{H})$ groups: $\mathrm{H}_{0-11}: 38.5^{\circ} \mathrm{C}$ high incubation temperature from days 0 to 11 of incubation, $\mathrm{H}_{12-21}: 38.5^{\circ} \mathrm{C}$ high incubation temperature from days 12 to 21 of incubation, $\mathrm{H}_{18-21}$ : $38.5^{\circ} \mathrm{C}$ high incubation temperature from days 18 to 21 of incubation at $21 \% \mathrm{O}_{2}$. All groups were incubated in three different single-stage incubators according to experimental design in Table 1. Prior to incubation, the average of the egg weights was $63.78 \pm 0.12 \mathrm{~g}$. The eggs at each incubator were pre-heated to $27^{\circ} \mathrm{C}$ for $8 \mathrm{~h}$ before initiated incubation. After $432 \mathrm{~h}$ of incubation, the eggs were candled, and those with living embryos were transferred to hatcher baskets at a temperature of $37.5^{\circ} \mathrm{C}$ and $68 \% \mathrm{RH}$, except for treatment groups. Incubator cabin conditions were presented as approximate values measurement per second by oximeters (PCEPHD 1, PCE Deutschland GmbH, Im Langel 4, D-59872 Meschede, Germany), air flow meters (PCE-PFM 2, PCE Deutschland $\mathrm{GmbH}$, Meschede, Germany), and a $\mathrm{CO}_{2} \log$ ger (Wöhler CDL 210, Schützenstr. 41, Germany). During incubation, air velocity was approximately $0.85 \mathrm{~m} \mathrm{~s}^{-1}$ and the $\mathrm{CO}_{2}$ value was approximately $557 \mathrm{ppm}$. Incubator conditions $\mathrm{RH}$, incubation temperature, and barometric pressure were, respectively, $58.50 \%, 59.76 \%$, and $59.43 \%$; 37.56 , 37.75 , and $37.61{ }^{\circ} \mathrm{C}$; and $623.28,621.21$, and $621.10 \mathrm{~mm} \mathrm{Hg}$ for the first incubator for incubation times of days 0 to 11 , days 12 to 17 , and days 18 to 21 , respectively. The respective conditions for the 2nd incubator were $57.59 \%, 58.34 \%$, and $57.80 \% ; 37.55,37.56$, and $37.51^{\circ} \mathrm{C}$; and $624.93,622.09$, and 
$621.17 \mathrm{~mm} \mathrm{Hg}$ for the respective incubation times mentioned above. For the 3rd incubator, the respective conditions were $58.64 \%, 58.51 \%$, and $58.93 \%$; $38.39,38.50$, and $38.46^{\circ} \mathrm{C}$; and $622.20,621.89$, and $621.32 \mathrm{~mm} \mathrm{Hg}$ for the same incubation times (days 0 to 11 , days 12 to 17 , days 18 to 21 , respectively). During incubation, conditions outside the incubators were $38.85 \%, 20.61^{\circ} \mathrm{C}$ and $830.26 \mathrm{hPa}$ for $\mathrm{RH}$, incubation temperature, and barometric pressure, respectively.

\subsection{Examined traits}

\subsubsection{Eggshell quality characteristics and eggshell temperature}

Determining each eggshell quality characteristics as a useful indicator of hatchability is important (Peebles and Brake, 1987) for the effects of manipulated IC on examined traits during pre-hatch hypoxic HA. Quality characteristics of 10 randomly selected eggs were measured, including weights of egg (g) and eggshells (g, \%), egg shape index (\%), eggshell thickness $(\mu \mathrm{m})$, average daily egg water loss $\left(\mathrm{mgd}^{-1}\right)$, eggshell conductance $\left(\mathrm{mg} \mathrm{H}_{2} \mathrm{Od}^{-1} \mathrm{Torr}^{-1}\right)$ by a saturation vapour conductance of $22.24 \mathrm{~mm} \mathrm{Hg}^{-1}$ at $23.6^{\circ} \mathrm{C}$ and relative eggshell conductance $\left(\mathrm{mg} \mathrm{H}_{2} \mathrm{O} \mathrm{d}^{-1} \mathrm{Torr}^{-1} 100 \mathrm{~g}^{-1}\right.$; Peebles and McDaniel, 2004), and eggshell surface area $\left(\mathrm{cm}^{2}\right.$; Narushin, 2005). Relative eggshell (dried shell plus membranes) weight was presented as percentage of the egg weight (EW). Egg shape index and eggshell surface area were determined by using formulas described below: egg shape index $=($ egg width $(\mathrm{mm}) /$ egg length $(\mathrm{mm})) \times 100$; eggshell surface area $\left(\mathrm{cm}^{2}\right)=3.9782 \times \mathrm{EW}^{0.7056}$. The EW, egg shape index, absolute and relative eggshell weight, average daily egg water loss, eggshell conductance and relative eggshell conductance, and eggshell surface area were $62.04 \mathrm{~g}, 78.40 \%$, $7.53 \mathrm{~g} 12.17 \%, 200.75 \mathrm{mg} \mathrm{d}^{-1}, 9.02 \mathrm{mg} \mathrm{H}_{2} \mathrm{O} \mathrm{d}^{-1} \mathrm{Torr}^{-1}$ and $14.04 \mathrm{mg} \mathrm{H}_{2} \mathrm{O} \mathrm{d}^{-1} \mathrm{Torr}^{-1} 100 \mathrm{~g}^{-1}$, and $73.21 \mathrm{~cm}^{2}$, respectively. Pore concentration (number per $0.25 \mathrm{~cm}^{-2}$ ), taken from eggshell pieces from the pointed, equatorial, and enlarged areas of the egg, was determined using a second set of eggs (10 eggs) as described by Peebles and McDaniel (2004). Pore diameters from 10 dying pores of three areas of the same eggshell were measured. Micro-images of the pore diameters were obtained with a $1024 \times$ magnification by EZ4 HD stereomicroscope and ICC50 HD camera (Leica Microsystems, Switzerland, 2010). Concentrations and values of pore diameter of the enlarged, equatorial, and pointed areas of eggshell were 27.02, 26.86, and 26.81 number per $0.25 \mathrm{~cm}^{-2}$; and $35.369,32.160$, and $29.617 \mu \mathrm{m}$, respectively. Eggshell temperatures were measured using an infrared thermometer (Ebro, TFI 550, D-85055 Ingolstadt, Germany) for a total of 210 eggs (5 candled eggs from IC/tray/day) at days $3,5,7,911,13,15,17$, and 19 of incubation.

\subsubsection{Hatching performance and rectal temperature}

A total of 210 eggs (5 candled eggs from IC/tray/day) were reweighed at days 11,14 , and 18 of incubation to calculate the relative egg water losses as described in the equation. Relative EW loss = ( ( EW of day $0-\mathrm{EW}$ on days 11,14 , and 18 of incubation) / EW of day 0$) \times 100$.

At hatching, rectal temperatures of 10 chicks from each group were measured using a thermocouple thermometer inserted approximately $1.2 \mathrm{~cm}$ into the colon. Hatchability of fertile eggs was defined as the percentage of hatched chicks per egg set tray. Eggs that failed to hatch were broken and assessed, and embryonic mortalities were defined as early (before 6 days), middle (7 to 15 days), or late (after 15 days) periods, and pipping (pipped shell but not emerged). Total embryonic mortality was calculated.

\subsubsection{Embryo/chick development and RV / TV ratio}

At days 13, 15, 17, and 19 of embryo development, 10 randomly selected eggs from each IC group were individually weighed, and weight losses were calculated in proportion to the initial egg weights. Eggs were opened and embryos killed by cervical dislocation, separated from residual yolk sac, and dissected tissues from embryo. Embryo, yolk sac, heart, liver, lung, brain, spleen, proventriculus + gizzard and bursa of fabricius were weighed to the nearest $0.001 \mathrm{~g}$. Relative weights of the organs and residual yolk sac were shown as a percentage of the absolute weight of embryo/chick. Dissected right ventricular and left ventricular + septum from heart trimmed off at the atria, major vessels, and fat were weighed. The right ventricular to total ventricular ratio (RV / TV) was determined and classified as described by Julian (1987). A RV / TV ratio of 0.25 is a normal RV hypertrophy and a RV / TV ratio between 0.25 and 0.29 is a moderate RV hypertrophy. The randomly selected seven female and seven male chicks from each IC group were weighed individually and all measurements were repeated at hatching.

\subsubsection{Blood sampling and analysis}

Fourteen newly hatched chicks per IC group were selected randomly to obtain blood samples. Blood samples were collected in biochemistry blood tubes by cardiac puncture of 14 chicks per IC group at hatching. Samples were centrifuged at $3500 \mathrm{rpm}$ for $10 \mathrm{~min}$ and serum was stored at $-20^{\circ} \mathrm{C}$ until analysed. Serum $\mathrm{T}_{3}$ and $\mathrm{T}_{4}$ levels were measured by chemiluminescence microparticle immunological analysis using Abbott ${ }^{\mathrm{TM}}$ kits (Architect free $\mathrm{T}_{3}$ B7K63T G4-6106/RO6 7K63 free $\mathrm{T}_{3}$ Reagent kit, Architect free $\mathrm{T}_{4} \mathrm{~B} 7 \mathrm{~K} 6 \mathrm{UT}$ G36099/RO1 7K65 free T 4 Reagent kit, Abbott Clinical Laboratories, USA) with an auto-analyser (Architect C8000, Abbott clinical chemistry analyser, Abbott Laboratories, USA). The serum $\mathrm{T}_{3}$ assay was characterized by intra-assay and inter-assay variations $(\mathrm{CV})$ of $2 \times 08$ and $3 \times 05 \%$, respectively. The serum $\mathrm{T}_{4}$ assay was characterized by intra-assay 
Table 1. The experimental design.

\begin{tabular}{llclclc}
\hline & 1st Incubator & $N$ & 2nd Incubator & $N$ & 3rd Incubator & $N$ \\
\hline Days 0 to 11 & Control, $\mathrm{O}_{12-21}, \mathrm{O}_{18-21}, \mathrm{H}_{12-21}, \mathrm{H}_{18-21}$ & 900 & $\mathrm{O}_{0-11}$ & 180 & $\mathrm{H}_{0-11}$ & 180 \\
Days 12 to 17 & Control, $\mathrm{O}_{0-11}, \mathrm{O}_{18-21}, \mathrm{H}_{0-11}, \mathrm{H}_{18-21}$ & 900 & $\mathrm{O}_{12-21}$ & 180 & $\mathrm{H}_{12-21}$ & 180 \\
Days 18 to 21 & Control, $\mathrm{O}_{0-11}, \mathrm{H}_{0-11}$ & 540 & $\mathrm{O}_{12-21}, \mathrm{O}_{18-21}$ & 360 & $\mathrm{H}_{12-21}, \mathrm{H}_{18-21}$ & 360 \\
\hline
\end{tabular}

and inter-assay variations $(\mathrm{CV})$ of $1 \times 87$ and $3 \times 65 \%$, respectively. Blood hemoglobin concentration was obtained after centrifugation (Hettich EBA 21 Centrifuge, GMI Inc., Minnesota, USA) at $3000 \mathrm{~g}$ for $10 \mathrm{~min}$, the cellular fraction was separated from the plasma and was then analysed colorimetrically with Biolabo reagent diagnostic kit (Biolabo Sa, Maizy, France) according to the manufacturer's instructions. Hematocrit values were measured from blood samples taken in capillary tubes at $13684 \times g$ for $5 \mathrm{~min}$ at $20^{\circ} \mathrm{C}$ using a haemocytometer (Laborzentrifugen $\mathrm{GmbH}$, Osterode am Harz, Germany).

\subsection{Statistical analysis}

Data were subjected to ANOVA with models, IC group (control, $\mathrm{O}_{0-11}, \mathrm{O}_{12-21}, \mathrm{H}_{0-11}$, and $\mathrm{H}_{12-21}$ ), and embryo age (on days 13, 15, 17, 19, and 21 of embryonic age). A second analysis for the $\mathrm{O}_{18-21}$ and $\mathrm{H}_{18-21}$ groups on days 19 and 21 of incubation was repeated across IC groups (control, $\mathrm{O}_{0-11}$, $\mathrm{O}_{12-21}, \mathrm{O}_{18-21}, \mathrm{H}_{0-11}, \mathrm{H}_{12-21}$, and $\mathrm{H}_{18-21}$ ) and embryo age (on days 13,15, 17, 19, and 21 of embryonic age), and interactions between them were treated as the main effects using the General Linear Model procedure from the JMP statistics package (SAS Institute Inc., 2007). Any trait determined to have an interaction was reanalysed by one-way ANOVA at each embryonic age. Eggshell temperature and hatching performance were analysed by one-way ANOVA. IC group, sex, and interaction effects were performed for the blood parameters at hatching. Least squares means were compared using the Tukey HSD (honest significant difference) test.

\section{Results}

\subsection{Eggshell temperature}

Eggshell temperature values are presented in Table 2. At day 3 of incubation, eggshell temperature was not different across the IC groups. The eggshell temperature was higher in the $\mathrm{H}$ groups, and the $\mathrm{O}_{18-21}$ group was not different from the control, compared to $\mathrm{O}_{0-11}$ and $\mathrm{O}_{12-21}$ groups, which were similar to the control on day 5 of incubation. The eggshell temperature was the highest in the $\mathrm{H}_{0-11}$ group compared to the control and the other groups, except for the $\mathrm{H}_{18-21}$ and $\mathrm{O}_{18-21}$ groups at day 7 of incubation (Table 2). On day 9 of incubation, the $\mathrm{O}_{0-11}$ group had the lowest eggshell temperature, and it was significantly different from the rest of the groups. There was no significant difference in eggshell temperatures on day 11 of incubation (Table 2). The highest eggshell temperature was significant for the $\mathrm{H}_{0-11}$ group compared with all of the groups that were on days 13 , 15,17 , and 19 of incubation (Table 2). Although the eggshell temperature decreased in the $\mathrm{O}_{12-21}$ group on days 15 and 17 of incubation, it was the lowest in the $\mathrm{H}_{12-21}$ and $\mathrm{H}_{18-21}$ groups relative to the $\mathrm{O}_{12-21}$ group on day 19 of incubation, but these groups were similar to the control at days 15,17 , and 19 of incubation (Table 2).

\subsection{Hatching performance}

Egg water loss was significantly increased in the $\mathrm{H}_{0-11}$ and $\mathrm{H}_{12-21}$ groups compared to other the groups at day 11 of incubation, but there were insignificant differences in egg water loss at day 14 of incubation (Table 3). On day 18 of incubation, the $\mathrm{O}_{0-11}$ and $\mathrm{O}_{12-21}$ groups had the lowest egg water losses, but these were not different from the control. Hatchability was $92.59 \%$ in the $\mathrm{O}_{12-21}$ group and $91.87 \%$ in the $\mathrm{O}_{18-21}$ group, different from the control group, compared with other groups. Whereas hatchability of the middle and late $\mathrm{H}$ groups was similar to $\mathrm{O}$ groups and the control, the early $\mathrm{H}$ group had the lowest hatchability compared to all treated groups (Table 3). Early embryonic mortality was similar in all groups, but $\mathrm{H}_{0-11}$ had the highest significant embryonic mortalities from days 0 to 7 and days 8 to 18 of incubation, when the $\mathrm{O}_{18-21}$ had the lowest in the group. Total embryonic mortality was the lowest in the $\mathrm{O}_{12-21}$ and $\mathrm{O}_{18-21}$ groups, and the highest rectal temperature was in the $\mathrm{O}_{12-21}$ group compared with the control, $\mathrm{O}_{18-21}$, or $\mathrm{H}_{0-11}$ groups (Table 3).

\subsection{Embryo/chick development}

\subsubsection{Embryo/chick weight}

Embryo weight (g and \% units) was the highest in the $\mathrm{H}_{12-21}$ group similar with the $\mathrm{H}_{0-11}$ group and the control, while it was lowest in the $\mathrm{O}_{0-11}$ group at day 13 of incubation (Table 4). On day 15 of incubation, the relative embryo weight decreased in the $\mathrm{O}_{0-11}$ group, unlike the control and $\mathrm{H}_{12-21}$ groups. On day 17 of incubation, absolute embryo weight of the $\mathrm{O}_{12-21}$ group was the highest compared with control, and the relative embryo weight of the $\mathrm{O}_{12-21}$ group was higher than the $\mathrm{H}$ groups (Table 4). The absolute and relative embryo weights did not show differences in the treated groups relative to the control at day 19 of incubation, and 
Table 2. Effects of incubation conditions (ICs) on eggshell temperature induced by hypoxia at high altitude in embryonated broiler eggs.

\begin{tabular}{|c|c|c|c|c|c|c|c|c|c|}
\hline \multirow{2}{*}{$\begin{array}{l}\text { Incubation } \\
\text { conditions } \mathrm{IC}^{\mathrm{d}}\end{array}$} & \multicolumn{9}{|c|}{ Days of incubation } \\
\hline & 3 & 5 & 7 & 9 & $\begin{array}{l}11 \\
{ }^{\circ} \mathrm{C}\end{array}$ & 13 & 15 & 17 & 19 \\
\hline $\mathrm{C}$ & 37.43 & $37.55^{\mathrm{ab}}$ & $36.53^{b}$ & $38.03^{\mathrm{ab}}$ & 36.55 & $37.40^{\mathrm{b}}$ & $37.39^{b c}$ & $37.48^{\mathrm{bc}}$ & $37.88^{\mathrm{bc}}$ \\
\hline $\mathrm{O}_{0-11}$ & 36.32 & $36.55^{\mathrm{b}}$ & $36.30^{\mathrm{b}}$ & $35.67^{\mathrm{c}}$ & 36.76 & $36.91^{b}$ & $36.91^{b c}$ & $36.36^{\mathrm{bc}}$ & $37.94^{\mathrm{bc}}$ \\
\hline $\mathrm{O}_{12-21}$ & 36.73 & $36.72^{\mathrm{b}}$ & $36.10^{\mathrm{b}}$ & $37.30^{\mathrm{b}}$ & 36.22 & $36.72^{\mathrm{b}}$ & $36.68^{\mathrm{c}}$ & $37.14^{\mathrm{c}}$ & $38.52^{b}$ \\
\hline $\mathrm{O}_{18-21}$ & 36.93 & $37.64^{\mathrm{a}}$ & $36.77^{\mathrm{ab}}$ & $38.12^{\mathrm{a}}$ & 36.19 & $37.60^{\mathrm{b}}$ & $37.53^{b c}$ & $37.91^{\mathrm{bc}}$ & $38.22^{\mathrm{bc}}$ \\
\hline $\mathrm{H}_{0-11}$ & 36.33 & $38.55^{\mathrm{a}}$ & $37.68^{\mathrm{a}}$ & $37.38^{\mathrm{ab}}$ & 37.50 & $39.30^{\mathrm{a}}$ & $39.27^{\mathrm{a}}$ & $39.20^{\mathrm{a}}$ & $39.33^{\mathrm{a}}$ \\
\hline $\mathrm{H}_{12-21}$ & 36.71 & $38.12^{\mathrm{a}}$ & $36.32^{\mathrm{b}}$ & $37.42^{\mathrm{a}}$ & 35.92 & $37.35^{\mathrm{b}}$ & $37.40^{\mathrm{bc}}$ & $37.60^{\mathrm{bc}}$ & $37.59^{c}$ \\
\hline $\mathrm{H}_{18-21}$ & 36.79 & $37.95^{\mathrm{a}}$ & $36.82^{\mathrm{ab}}$ & $37.77^{\mathrm{ab}}$ & 36.11 & $37.61^{\mathrm{b}}$ & $37.67^{\mathrm{bc}}$ & $38.04^{\mathrm{b}}$ & $37.67^{\mathrm{c}}$ \\
\hline SEM & 0.49 & 0.42 & 0.35 & 0.28 & 0.40 & 0.32 & 0.30 & 0.28 & 0.27 \\
\hline$P$ value & 0.149 & 0.009 & 0.038 & $<0.001$ & 0.097 & $<0.001$ & $<0.001$ & $<0.001$ & $<0.001$ \\
\hline
\end{tabular}

a-c Means within a column with different superscript differ significantly at $P<0.05 ; n=18$

${ }^{\mathrm{d}} \mathrm{C}$ : control, $\mathrm{O}_{0-11}: 23.5 \% \mathrm{O}_{2}$ supplementation between days 0 and 11 of incubation, $\mathrm{O}_{12-21}: 23.5 \% \mathrm{O}_{2}$ supplementation between days 12 and 21 of incubation, $\mathrm{O}_{18-21}: 23.5 \% \mathrm{O}_{2}$ supplementation between days 18 and 21 of incubation, $\mathrm{H}_{0-11}: 38.5^{\circ} \mathrm{C}$ high incubation temperature between days 0 and 11 of incubation, $\mathrm{H}_{12-21}: 38.5^{\circ} \mathrm{C}$ high incubation temperature between days 12 and 21 of incubation, $\mathrm{H}_{18-21}: 38.5^{\circ} \mathrm{C}$ high incubation temperature between days 18 and 21 of incubation. SEM: standard error means.

Table 3. Effects of incubation conditions on egg water loss of broilers on days 11, 14 and 18 of incubation, hatchability, embryonic mortalities, and rectal temperature induced by hypoxia at high altitude of chicks at hatching.

\begin{tabular}{|c|c|c|c|c|c|c|c|c|c|c|}
\hline \multirow{3}{*}{$\begin{array}{l}\text { Incubation } \\
\text { conditions } \\
\mathrm{IC}^{\mathrm{d}}\end{array}$} & \multicolumn{3}{|c|}{$\begin{array}{c}\text { Egg water loss, } \\
\%\end{array}$} & \multirow[t]{3}{*}{$\begin{array}{l}\text { Hatchability, } \\
\%\end{array}$} & \multicolumn{5}{|c|}{$\begin{array}{c}\text { Embryonic mortalities, } \\
\%\end{array}$} & \multirow{3}{*}{$\begin{array}{l}\text { Rectal } \\
\text { temperature, } \\
{ }^{\circ} \mathrm{C}\end{array}$} \\
\hline & \multicolumn{3}{|c|}{ Days of incubation } & & Days 0 & Days 8 & Days 19 & Non- & Total & \\
\hline & 11 & 14 & 18 & & & & & & & \\
\hline $\mathrm{C}$ & $6.12^{\mathrm{b}}$ & 7.25 & $10.07^{\mathrm{ab}}$ & $76.68^{b}$ & $4.73^{b}$ & $2.35^{\mathrm{b}}$ & 10.02 & 2.35 & $18.27^{b}$ & $36.52^{\mathrm{c}}$ \\
\hline $\mathrm{O}_{0-11}$ & $5.79^{b}$ & 4.93 & $8.84^{\mathrm{b}}$ & $78.40^{\mathrm{b}}$ & $2.99^{b}$ & $2.26^{\mathrm{b}}$ & 8.75 & 5.54 & $18.16^{\mathrm{b}}$ & $37.87^{\mathrm{abc}}$ \\
\hline $\mathrm{O}_{12-21}$ & $5.58^{\mathrm{b}}$ & 9.29 & $9.03^{b}$ & $92.59^{a}$ & $0.57^{\mathrm{b}}$ & $1.16^{\mathrm{b}}$ & 2.28 & 3.41 & $5.72^{\mathrm{c}}$ & $38.13^{\mathrm{a}}$ \\
\hline $\mathrm{O}_{18-21}$ & $6.08^{b}$ & 9.05 & $11.03^{\mathrm{a}}$ & $91.87^{\mathrm{a}}$ & $1.74^{\mathrm{b}}$ & $0.57^{\mathrm{c}}$ & 4.10 & - & $6.41^{\mathrm{c}}$ & $36.67^{\mathrm{bc}}$ \\
\hline $\mathrm{H}_{0-11}$ & $8.08^{\mathrm{a}}$ & 10.08 & $11.24^{\mathrm{a}}$ & $39.95^{\mathrm{c}}$ & $22.05^{\mathrm{a}}$ & $20.28^{\mathrm{a}}$ & 10.96 & - & $53.31^{\mathrm{a}}$ & $36.45^{\mathrm{c}}$ \\
\hline $\mathrm{H}_{12-21}$ & $7.83^{\mathrm{a}}$ & 9.81 & $10.91^{\mathrm{a}}$ & $84.00^{\mathrm{ab}}$ & $0.58^{\mathrm{b}}$ & $4.01^{\mathrm{b}}$ & 9.16 & 2.22 & $14.30^{\mathrm{b}}$ & $37.25^{\mathrm{abc}}$ \\
\hline $\mathrm{H}_{18-21}$ & $5.92^{\mathrm{b}}$ & 8.42 & $10.47^{\mathrm{a}}$ & $84.11^{\mathrm{ab}}$ & $3.69^{\mathrm{b}}$ & $4.23^{\mathrm{b}}$ & 9.42 & 2.45 & $18.54^{\mathrm{b}}$ & $37.53^{\mathrm{abc}}$ \\
\hline SEM & 0.44 & 1.52 & 1.23 & 2.35 & 0.83 & 0.55 & 0.78 & 0.27 & 2.15 & 0.44 \\
\hline$P$ value & $<0.001$ & 0.410 & 0.026 & $<0.001$ & $<0.001$ & 0.004 & 0.235 & 0.393 & $<0.001$ & 0.038 \\
\hline
\end{tabular}

a-c Means within a column with different superscript differ significantly at $P<0.05$.

${ }^{\mathrm{d}} \mathrm{C}$ : control, $\mathrm{O}_{0-11}: 23.5 \% \mathrm{O}_{2}$ supplementation between days 0 and 11 of incubation, $\mathrm{O}_{12-21}: 23.5 \% \mathrm{O}_{2}$ supplementation between days 12 and 21 of incubation, $\mathrm{O}_{18-21}: 23.5 \% \mathrm{O}_{2}$ supplementation between days 18 and 21 of incubation, $\mathrm{H}_{0-11}: 38.5^{\circ} \mathrm{C}$ high incubation temperature between days 0 and 11 of incubation, $\mathrm{H}_{12-21}$ : $38.5^{\circ} \mathrm{C}$ high incubation temperature between days 12 and 21 of incubation, $\mathrm{H}_{18-21}: 38.5^{\circ} \mathrm{C}$ high incubation temperature between days 18 and 21 of incubation. SEM: standard error means.

chick weight was not different in the IC groups at hatching (Table 4).

\subsubsection{Yolk sac weight}

The highest yolk sac weight was in the $\mathrm{O}$ groups, but the $0_{12-21}$ group was not different from other groups on day 15 of incubation (Table 4). On the same day, the relative yolk sac weight of the $\mathrm{O}_{0-11}$ and $\mathrm{H}_{12-21}$ groups were higher than that of the $\mathrm{H}_{0-11}$ group. On day 17 of incubation, the $\mathrm{O}$ groups had the highest absolute yolk sac weight, but $\mathrm{O}$ groups were not different from the $\mathrm{H}_{0-11}$ group for the absolute yolk sac weight (Table 4). On the same day, the relative weight of the yolk sac from the $\mathrm{H}_{12-21}$ group was significantly lower than the other groups (Table 4). On day 19 of incubation, the $\mathrm{H}_{0-11}$ group had a lower yolk sac weight (g and \%) than that of all groups, whereas it had the highest yolk sac weights at hatching (Table 4). Similar results were obtained for the $\mathrm{H}_{12-21}$ group at hatching (Table 4). 
Table 4. Effects of incubation conditions and embryo age (at days 13, 15, 17, 19, and 21 of embryo development) on weights of embryo (g, $\%)$, yolk sac $(\mathrm{g}, \%)$, heart $(\mathrm{g}, \%)$, right ventricular $(\mathrm{g})$, left ventricular+septum $(\mathrm{g})$, total ventricular $(\mathrm{g})$, and right ventricular weight to total ventricular weight ratio induced by hypoxia at high altitude.

\begin{tabular}{|c|c|c|c|c|c|c|c|c|c|c|c|}
\hline & \multirow{2}{*}{$\begin{array}{l}\text { Incubation } \\
\text { conditions } \\
\mathrm{IC}^{\mathrm{d}}\end{array}$} & \multicolumn{2}{|c|}{ Embryo weight } & \multicolumn{2}{|c|}{$\begin{array}{l}\text { Yolk sac } \\
\text { weight }\end{array}$} & \multicolumn{2}{|c|}{ Heart weight } & \multirow{2}{*}{$\begin{array}{l}\text { RV } \\
\text { weight } \\
\mathrm{g}\end{array}$} & \multirow{2}{*}{$\begin{array}{l}\text { LV + } \\
\text { septum } \\
\text { weight } \\
\text { g }\end{array}$} & \multirow{2}{*}{$\begin{array}{l}\text { TV } \\
\text { weight } \\
\mathrm{g}\end{array}$} & \multirow[t]{2}{*}{$\mathrm{RV} / \mathrm{TV}$} \\
\hline & & $\mathrm{g}$ & $\%$ & $\mathrm{~g}$ & $\%$ & $\mathrm{~g}$ & $\%$ & & & & \\
\hline \multicolumn{12}{|l|}{ Age, days } \\
\hline \multirow[t]{6}{*}{13} & $\mathrm{C}$ & $9.90^{\mathrm{ab}}$ & $16.17^{\mathrm{ab}}$ & - & - & 0.070 & 0.71 & 0.013 & $0.047^{\mathrm{ab}}$ & $0.060^{\mathrm{ab}}$ & 0.22 \\
\hline & $\mathrm{O}_{0-11}$ & $7.68^{\mathrm{c}}$ & $12.67^{\mathrm{c}}$ & - & - & 0.062 & 0.81 & 0.011 & $0.042^{\mathrm{b}}$ & $0.054^{\mathrm{b}}$ & 0.22 \\
\hline & $\mathrm{O}_{12-21}$ & $9.34^{\mathrm{b}}$ & $15.56^{\mathrm{b}}$ & - & - & 0.071 & 0.77 & 0.014 & $0.051^{\mathrm{a}}$ & $0.065^{\mathrm{a}}$ & 0.21 \\
\hline & $\mathrm{H}_{0-11}$ & $9.76^{\mathrm{ab}}$ & $16.36^{\mathrm{ab}}$ & - & - & 0.065 & 0.68 & 0.013 & $0.041^{b}$ & $0.054^{\mathrm{b}}$ & 0.24 \\
\hline & $\mathrm{H}_{12-21}$ & $10.24^{\mathrm{a}}$ & $17.50^{\mathrm{a}}$ & - & - & 0.077 & 0.76 & 0.013 & $0.052^{\mathrm{a}}$ & $0.065^{\mathrm{a}}$ & 0.20 \\
\hline & SEM & 0.31 & 0.60 & - & - & 0.004 & 0.05 & 0.001 & 0003 & 0.003 & 0.01 \\
\hline \multirow[t]{6}{*}{15} & $\mathrm{C}$ & 16.31 & $27.55^{\mathrm{a}}$ & $13.02^{\mathrm{b}}$ & $22.51^{\mathrm{ab}}$ & 0.130 & 0.79 & 0.021 & 0.075 & 0.096 & 0.22 \\
\hline & $\mathrm{O}_{0-11}$ & 15.67 & $24.63^{c}$ & $16.85^{\mathrm{a}}$ & $26.43^{\mathrm{a}}$ & 0.127 & 0.80 & 0.018 & 0.080 & 0.099 & 0.18 \\
\hline & $\mathrm{O}_{12-21}$ & 15.57 & $25.96^{\mathrm{abc}}$ & $14.33^{\mathrm{ab}}$ & $23.89^{\mathrm{ab}}$ & 0.134 & 0.86 & 0.022 & 0.085 & 0.108 & 0.21 \\
\hline & $\mathrm{H}_{0-11}$ & 14.90 & $25.32^{b c}$ & $11.35^{\mathrm{b}}$ & $19.21^{\mathrm{b}}$ & 0.114 & 0.77 & 0.019 & 0.075 & 0.094 & 0.20 \\
\hline & $\mathrm{H}_{12-21}$ & 16.25 & $28.40^{\mathrm{ab}}$ & $13.95^{\mathrm{b}}$ & $24.52^{\mathrm{a}}$ & 0.119 & 0.72 & 0.019 & 0.077 & 0.096 & 0.19 \\
\hline & SEM & 0.44 & 0.93 & 0.89 & 1.88 & 0.006 & 0.04 & 0.002 & 0.004 & 0.004 & 0.01 \\
\hline \multirow[t]{6}{*}{17} & $\mathrm{C}$ & $22.10^{\mathrm{ab}}$ & $38.52^{\mathrm{ab}}$ & $10.91^{\mathrm{b}}$ & $19.16^{\mathrm{bc}}$ & $0.144^{b}$ & 0.66 & $0.025^{\mathrm{b}}$ & $0.081^{\mathrm{b}}$ & $0.010^{\mathrm{b}}$ & 0.26 \\
\hline & $\mathrm{O}_{0-11}$ & $20.94^{\mathrm{b}}$ & $36.78^{\mathrm{abc}}$ & $13.41^{\mathrm{a}}$ & $23.64^{\mathrm{a}}$ & $0.146^{\mathrm{b}}$ & 0.70 & $0.023^{\mathrm{b}}$ & $0.077^{\mathrm{b}}$ & $0.010^{\mathrm{b}}$ & 0.25 \\
\hline & $\mathrm{O}_{12-21}$ & $23.90^{\mathrm{a}}$ & $38.94^{\mathrm{a}}$ & $14.08^{\mathrm{a}}$ & $23.02^{\mathrm{ab}}$ & $0.202^{\mathrm{a}}$ & 0.85 & $0.032^{\mathrm{a}}$ & $0.105^{\mathrm{a}}$ & $0.014^{\mathrm{a}}$ & 0.24 \\
\hline & $\mathrm{H}_{0-11}$ & $20.11^{\mathrm{b}}$ & $35.48^{\mathrm{bc}}$ & $12.78^{a b}$ & $24.04^{\mathrm{a}}$ & $0.133^{b}$ & 0.67 & $0.022^{\mathrm{b}}$ & $0.065^{\mathrm{b}}$ & $0.09^{\mathrm{b}}$ & 0.23 \\
\hline & $\mathrm{H}_{12-21}$ & $20.70^{\mathrm{b}}$ & $34.17^{\mathrm{c}}$ & $10.43^{\mathrm{b}}$ & $17.66^{\mathrm{c}}$ & $0.121^{b}$ & 0.59 & $0.024^{\mathrm{b}}$ & $0.071^{b}$ & $0.09^{\mathrm{b}}$ & 0.23 \\
\hline & SEM & 0.72 & 1.08 & 0.81 & 1.57 & 0.009 & 0.04 & 0.001 & 0.006 & 0.01 & 0.01 \\
\hline \multirow[t]{8}{*}{19} & $\mathrm{C}$ & $29.95^{\mathrm{abc}}$ & $52.09^{\mathrm{ab}}$ & $12.89^{\mathrm{a}}$ & $22.48^{\mathrm{a}}$ & $0.19^{\mathrm{ab}}$ & 0.64 & $0.021^{b}$ & $0.113^{\mathrm{bc}}$ & $0.13^{\mathrm{bc}}$ & $0.15^{\mathrm{b}}$ \\
\hline & $\mathrm{O}_{0-11}$ & $28.64^{\mathrm{c}}$ & $53.32^{\mathrm{a}}$ & $12.09^{\mathrm{a}}$ & $22.38^{\mathrm{a}}$ & $0.18^{\mathrm{b}}$ & 0.65 & $0.027^{\mathrm{ab}}$ & $0.103^{c}$ & $0.13^{b c}$ & $0.20^{\mathrm{a}}$ \\
\hline & $\mathrm{O}_{12-21}$ & $31.80^{\mathrm{ab}}$ & $53.30^{\mathrm{a}}$ & $12.79^{\mathrm{a}}$ & $21.48^{\mathrm{a}}$ & $0.22^{\mathrm{a}}$ & 0.71 & $0.033^{\mathrm{a}}$ & $0.140^{\mathrm{a}}$ & $0.17^{\mathrm{a}}$ & $0.19^{\mathrm{a}}$ \\
\hline & $\mathrm{O}_{18-21}$ & $32.55^{\mathrm{a}}$ & $54.66^{\mathrm{a}}$ & $11.45^{\mathrm{a}}$ & $19.23^{\mathrm{a}}$ & $0.20^{\mathrm{ab}}$ & 0.63 & $0.028^{\mathrm{ab}}$ & $0.120^{\mathrm{ab}}$ & $0.15^{\mathrm{ab}}$ & $0.19^{\mathrm{a}}$ \\
\hline & $\mathrm{H}_{0-11}$ & $28.76^{\mathrm{bc}}$ & $47.57^{\mathrm{b}}$ & $9.55^{\mathrm{b}}$ & $15.84^{\mathrm{b}}$ & $0.19^{\mathrm{ab}}$ & 0.67 & $0.020^{\mathrm{b}}$ & $0.091^{\mathrm{c}}$ & $0.11^{\mathrm{c}}$ & $0.17^{\mathrm{ab}}$ \\
\hline & $\mathrm{H}_{12-21}$ & $29.95^{\mathrm{abc}}$ & $52.17^{\mathrm{ab}}$ & $12.69^{\mathrm{a}}$ & $22.16^{\mathrm{a}}$ & $0.18^{\mathrm{b}}$ & 0.59 & $0.022^{\mathrm{b}}$ & $0.092^{\mathrm{c}}$ & $0.12^{c}$ & $0.19^{\mathrm{a}}$ \\
\hline & $\mathrm{H}_{18-21}$ & $29.77^{\mathrm{abc}}$ & $50.76^{\mathrm{ab}}$ & $12.35^{\mathrm{a}}$ & $21.04^{\mathrm{a}}$ & $0.18^{\mathrm{b}}$ & 0.60 & $0.023^{b}$ & $0.100^{\mathrm{bc}}$ & $0.13^{b c}$ & $0.17^{\mathrm{ab}}$ \\
\hline & SEM & 0.38 & 0.62 & 0.31 & 0.82 & 0.004 & 0.01 & 0.001 & 0.003 & 0.003 & 0.004 \\
\hline \multirow[t]{8}{*}{ Hatching } & $\mathrm{C}$ & 45.68 & - & $6.51^{\mathrm{c}}$ & $14.34^{\mathrm{b}}$ & $0.25^{\mathrm{c}}$ & 0.55 & $0.048^{b}$ & $0.19^{\mathrm{b}}$ & $0.24^{\mathrm{b}}$ & 0.20 \\
\hline & $\mathrm{O}_{0-11}$ & 46.54 & - & $7.88^{\mathrm{bc}}$ & $16.94^{\mathrm{b}}$ & $0.24^{\mathrm{c}}$ & 0.52 & $0.048^{\mathrm{b}}$ & $0.18^{\mathrm{b}}$ & $0.24^{\mathrm{b}}$ & 0.20 \\
\hline & $\mathrm{O}_{12-21}$ & 45.11 & - & $7.19^{c}$ & $16.00^{\mathrm{b}}$ & $0.28^{\mathrm{ab}}$ & 0.63 & $0.055^{\mathrm{a}}$ & $0.22^{\mathrm{a}}$ & $0.28^{\mathrm{a}}$ & 0.19 \\
\hline & $\mathrm{O}_{18-21}$ & 44.95 & - & $6.99^{c}$ & $15.50^{\mathrm{b}}$ & $0.29^{\mathrm{a}}$ & 0.65 & $0.058^{\mathrm{a}}$ & $0.23^{\mathrm{a}}$ & $0.29^{\mathrm{a}}$ & 0.20 \\
\hline & $\mathrm{H}_{0-11}$ & 44.53 & - & $9.84^{\mathrm{ab}}$ & $22.33^{\mathrm{a}}$ & $0.24^{\mathrm{c}}$ & 0.55 & $0.049^{\mathrm{b}}$ & $0.19^{\mathrm{b}}$ & $0.24^{\mathrm{b}}$ & 0.20 \\
\hline & $\mathrm{H}_{12-21}$ & 45.30 & - & $9.93^{\mathrm{a}}$ & $21.93^{\mathrm{a}}$ & $0.24^{\mathrm{c}}$ & 0.54 & $0.047^{b}$ & $0.18^{\mathrm{b}}$ & $0.22^{\mathrm{b}}$ & 0.21 \\
\hline & $\mathrm{H}_{18-21}$ & 45.48 & - & $7.00^{\mathrm{c}}$ & $15.46^{\mathrm{b}}$ & $0.26^{\mathrm{bc}}$ & 0.57 & $0.048^{b}$ & $0.19^{\mathrm{b}}$ & $0.24^{\mathrm{b}}$ & 0.20 \\
\hline & SEM & 0.30 & - & 0.27 & 0.71 & 0.004 & 0.01 & 0.001 & 0.002 & 0.003 & 0.003 \\
\hline \multirow[t]{3}{*}{$P$ value } & IC & 0.009 & 0.012 & 0.661 & 0.016 & $<0.001$ & $<0.001$ & $<0.001$ & $<0.001$ & $<0.001$ & 0.275 \\
\hline & Age & $<0.001$ & $<0.001$ & $<0.001$ & 0.037 & $<0.001$ & $<0.001$ & $<0.001$ & $<0.001$ & $<0.001$ & $<0.001$ \\
\hline & IC $\times$ Age & 0.021 & 0.001 & $<0.001$ & 0.015 & 0.005 & 0.310 & 0.282 & 0.006 & 0.004 & 0.175 \\
\hline
\end{tabular}

a-c Means within a column for each of embryonic age with different superscript differ significantly at $P<0.05$.

${ }^{\mathrm{d}} \mathrm{C}$ : control, $\mathrm{O}_{0-11}: 23.5 \% \mathrm{O}_{2}$ supplementation between days 0 and 11 of incubation, $\mathrm{O}_{12-21}: 23.5 \% \mathrm{O}_{2}$ supplementation between days 12 and 21 of incubation, $\mathrm{O}_{18-21}: 23.5 \% \mathrm{O}_{2}$ supplementation between days 18 and 21 of incubation, $\mathrm{H}_{0-11}: 38.5^{\circ} \mathrm{C}$ high incubation temperature between days 0 and 11 of incubation, $\mathrm{H}_{12-21}: 38.5^{\circ} \mathrm{C}$ high incubation temperature between days 12 and 21 of incubation, $\mathrm{H}_{18-21}: 38.5^{\circ} \mathrm{C}$ high incubation temperature between days 18 and 21 of incubation.

$\mathrm{RV}$ : right ventricular; LV: left ventricular; TV: total ventricular; RV / TV: right ventricular weight to total ventricular weight ratio. SEM: standard error means.

\subsubsection{Organ weights and indicators of RV / TV ratio}

The absolute heart weight was significantly higher in the $\mathrm{O}_{12-21}$ group than the other groups on day 17 of incubation
(Table 4). Similar results were obtained on day 19 of incubation, but the $\mathrm{O}_{12-21}$ group was not different from the control, $\mathrm{O}_{18-21}$, or $\mathrm{H}_{0-11}$ groups. At hatching, the highest heart weight (g) was found in the $\mathrm{O}_{12-21}$ group, which was not 
different from the $\mathrm{H}_{18-21}$, or $\mathrm{O}_{18-21}$ groups. (Table 4). At day 17 of incubation, the right ventricular (RV), left ventricular (LV) + septum, and total ventricular (TV) weights were higher in the $\mathrm{O}_{12-21}$ group than in other groups (Table 4). At day 19 of incubation, the highest $\mathrm{RV}$ weight was in all $\mathrm{O}_{2}$ groups, but the $\mathrm{O}_{0-11}$ and $\mathrm{O}_{18-21}$ groups were not different from the control and other treatment groups. The highest LV + septum and TV weights were in the $\mathrm{O}_{12-21}$ groups similar to the $\mathrm{O}_{18-21}$ group at day 19 of incubation (Table 4). At hatching, the highest RV, LV + septum, and TV weights were in the $\mathrm{O}_{12-21}$ and $\mathrm{O}_{18-21}$ groups compared to other groups (Table 4). The RV / TV ratio was similar to the control in the $\mathrm{H}_{0-11}$ and $\mathrm{H}_{18-21}$ groups relative to other groups at day 19 of incubation, although it was not different in groups at other embryonic ages (Table 4).

Absolute liver weight significantly decreased in both treatment groups from days 0 to 11 of incubation and on day 13 of incubation, whereas it was lower in the $\mathrm{H}_{0-11}$ than groups from days 18 to 21 of incubation at hatching (Table 5). Relative liver weight was the lowest in the $\mathrm{O}_{12-21}$ group and was the highest in the $\mathrm{H}_{12-21}$ group at day 17 of incubation. While relative liver weight was found to be the lowest in both treatment groups from days 0 to 11 of incubation, it was determined that it was the highest in both treatment groups from days 18 to 21 of incubation at hatching (Table 5).

Absolute brain weight decreased in the $\mathrm{H}_{0-11}$ group compared with control group at days 13 and 19 of incubation. The absolute brain weight of the $\mathrm{H}_{0-11}$ group was different from the $\mathrm{H}_{18-21}$ and $\mathrm{O}_{0-11}$ groups at hatching (Table 5). The highest relative brain weight was found in the $\mathrm{O}_{0-11}$ group, and the lowest value was found in the $\mathrm{H}_{0-11}$ group, which was similar to the control at day 13 of incubation (Table 5). At day 17 of incubation, treatment groups at the middle period of incubation had decreased in relative brain weight compared to the $\mathrm{H}_{0-11}$ group, which had the highest brain weight (\%) similar to the control, $\mathrm{O}_{0-11}$, and $\mathrm{H}_{12-21}$ groups (Table 5). Relative brain weight significantly decreased in the $\mathrm{H}_{0-11}$ group relative to the increase in the $\mathrm{H}_{12-21}$ group, which only was different from the $\mathrm{O}_{12-21}$ group at day 19 of incubation. Proventriculus + gizzard weight $(\mathrm{g})$ was lower in the $\mathrm{O}_{0-11}$ group than the control and other groups at day 13 of incubation. A similar pattern was observed in the $\mathrm{O}_{0-11}$ group, but it was only different from the control at day 15 of incubation. Compared with control and the middle- and lateperiod $\mathrm{O}$ groups, the $\mathrm{H}_{0-11}$ and $\mathrm{H}_{12-21}$ groups had the lowest proventriculus + gizzard weight $(\mathrm{g})$ at hatching, although treatment groups were similar to the control at day 19 of incubation (Table 5). The highest differential relative proventriculus + gizzard weight was obtained from the control and the treatment groups from days 12 to 21 and at day 13 of incubation, whereas treatment groups were not different from the control for relative brain weight at day 17 of incubation and hatch (Table 5). The lowest lung weights ( $\mathrm{g}$ and \%) were found in the $\mathrm{H}_{0-11}$ group compared to the other groups at day 13 of incubation, while the lowest lung weight (g) was found in the $\mathrm{H}_{12-21}$ group compared to the other groups at day 17 of incubation. The relative lung weights of the treatment groups were not different from the control at day 17 of incubation and at hatching, where treatment groups were not different from the control for absolute lung weight (Table 5). At day 19 of incubation, the bursa of fabricius weights ( $g$ and $\%$ ) were lower in the $\mathrm{O}_{0-11}$ group than control. At hatching, the highest absolute bursa of fabricius weight was found in the $\mathrm{H}_{18-21}$ group, whereas the lowest absolute bursa of fabricius weight was found in the $\mathrm{H}_{0-11}$ group (Table 5). Compared to the control and other groups, the $\mathrm{H}_{12-21}$ group had the lowest relative bursa of fabricius weight at hatching. The absolute and relative spleen weights in all $\mathrm{O}$ and $\mathrm{H}$ groups were similar to the control at the examined embryonic ages (Table 5).

\subsubsection{Blood parameters}

The effect of IC was significant on all blood parameters. The chicks from the $\mathrm{O}_{12-21}$ group had significantly higher serum $\mathrm{T}_{3}$ concentration than the chicks from $\mathrm{O}$ groups or the control, which had the lowest serum $\mathrm{T}_{3}$ concentration distinct from the $\mathrm{H}$ groups. The serum $\mathrm{T}_{4}$ concentration of the treated groups was higher than the control, except for the $\mathrm{H}_{12-21}$ and $\mathrm{O}_{18-21}$ groups. The $\mathrm{T}_{3} / \mathrm{T}_{4}$ ratio was the lowest in the $\mathrm{O}_{0-11}$ group, but the $\mathrm{T}_{3} / \mathrm{T}_{4}$ ratio of $\mathrm{O}_{0-11}$ group did not show a difference from the control, $\mathrm{O}_{18-21}$, or $\mathrm{H}_{0-11}$ groups. The blood hemoglobin concentration of the $\mathrm{O}$ groups decreased relative to chicks from the control and $\mathrm{H}$ groups, except for the $\mathrm{H}_{0-11}$ group. The blood hematocrit value was significantly the lowest in the $\mathrm{O}_{12-21}$ and the highest in the $\mathrm{H}_{12-21}$ groups, but it was not different from the $\mathrm{H}_{18-21}$ group. The sex effect was significant for the serum $\mathrm{T}_{4}$ concentration, which it was increased in male chicks compared with female chicks. The sex effect was insignificant for serum $\mathrm{T}_{3}$ concentration, $\mathrm{T}_{3} / \mathrm{T}_{4}$ ratio, blood hemoglobin, and hematocrit values at hatching (Table 6).

\section{Discussion}

The main reason for this study was to achieve optimal hatchability and chick development by changing physiological systems of the embryo when provided with a combination of macro- and micro-environmental conditions of the eggs during incubation by key factors such as appropriate IC, period, and feature of any IC (Tong et al., 2013). During embryogenesis, the formation of organ systems occurs at day 11 of incubation, the early embryogenesis stage. After this stage, growth and maturation of embryo occurs at the middle to late embryogenesis stages. In this study, only $\mathrm{H}$ administration at an early embryonic stage affected eggshell temperature at day 7 of embryonic age when the body begins to develop rapidly, and the heart is completely enclosed in the thoracic cavity and the vitelline system transports nutrients from yolk sac to embryo (Dawson and Whittow, 2000). When consider- 
Table 5. Effects of incubation conditions and embryo age (at days 13, 15, 17, 19, and 21 of embryo development) on weights of liver (g, \%), brain $(\mathrm{g}, \%)$, proventriculus and gizzard $(\mathrm{g}, \%)$, lung $(\mathrm{g}, \%)$, bursa of fabricius $(\mathrm{g}, \%)$, and spleen (g, \%) induced by hypoxia at high altitude.

\begin{tabular}{|c|c|c|c|c|c|c|c|c|c|c|c|c|c|}
\hline & \multirow[t]{2}{*}{$\begin{array}{l}\text { Incubation } \\
\text { conditions } \\
\mathrm{IC}^{\mathrm{d}}\end{array}$} & \multicolumn{2}{|c|}{ Liver weight } & \multicolumn{2}{|c|}{ Brain weight } & \multicolumn{2}{|c|}{$\begin{array}{c}\text { Proventriculus } \\
+ \text { gizzard } \\
\text { weight }\end{array}$} & \multicolumn{2}{|c|}{ Lung weight } & \multicolumn{2}{|c|}{$\begin{array}{c}\text { bursa of fabricius } \\
\text { weight }\end{array}$} & \multicolumn{2}{|c|}{ Spleen weight } \\
\hline & & g & $\%$ & g & $\%$ & g & $\%$ & $\mathrm{~g}$ & $\%$ & $\mathrm{~g}$ & $\%$ & g & $\%$ \\
\hline Age days & & & & & & & & & & & & & \\
\hline 13 & $\begin{array}{l}\mathrm{C} \\
\mathrm{O}_{0-11} \\
\mathrm{O}_{12-21} \\
\mathrm{H}_{0-11} \\
\mathrm{H}_{12-21} \\
\text { SEM }\end{array}$ & $\begin{array}{l}0.188^{\mathrm{a}} \\
0.153^{\mathrm{c}} \\
0.187^{\mathrm{ab}} \\
0.165^{\mathrm{bc}} \\
0.197^{\mathrm{a}} \\
0.01\end{array}$ & $\begin{array}{l}1.90 \\
1.91 \\
2.01 \\
1.73 \\
1.93 \\
0.09\end{array}$ & $\begin{array}{l}0.32^{\mathrm{ab}} \\
0.30^{\mathrm{b}} \\
0.33^{\mathrm{ab}} \\
0.30^{\mathrm{b}} \\
0.36^{\mathrm{a}} \\
0.01\end{array}$ & $\begin{array}{l}3.24^{\mathrm{b}} \\
3.88^{\mathrm{a}} \\
3.52^{\mathrm{ab}} \\
3.16^{\mathrm{b}} \\
3.57^{\mathrm{ab}} \\
0.17\end{array}$ & $\begin{array}{l}0.218^{\mathrm{b}} \\
0.173^{\mathrm{c}} \\
0.255^{\mathrm{ab}} \\
0.245^{\mathrm{ab}} \\
0.278^{\mathrm{a}} \\
0.01\end{array}$ & $\begin{array}{l}2.20^{\mathrm{b}} \\
2.25^{\mathrm{b}} \\
2.74^{\mathrm{a}} \\
2.57^{\mathrm{ab}} \\
2.71^{\mathrm{a}} \\
0.13\end{array}$ & $\begin{array}{l}0.164^{\mathrm{ab}} \\
0.156^{\mathrm{bc}} \\
0.156^{\mathrm{bc}} \\
0.126^{\mathrm{c}} \\
0.193^{\mathrm{a}} \\
0.01\end{array}$ & $\begin{array}{l}1.68^{\mathrm{ab}} \\
2.03^{\mathrm{a}} \\
1.67^{\mathrm{ab}} \\
1.34^{\mathrm{c}} \\
1.88^{\mathrm{a}} \\
0.13\end{array}$ & $\begin{array}{l}0.015 \\
0.019 \\
0.016 \\
0.017 \\
0.013 \\
0.02\end{array}$ & $\begin{array}{l}0.147 \\
0.257 \\
0.176 \\
0.187 \\
0.125 \\
0.05\end{array}$ & $\begin{array}{l}- \\
- \\
- \\
- \\
- \\
-\end{array}$ & $\begin{array}{l}- \\
- \\
- \\
-\end{array}$ \\
\hline 15 & $\begin{array}{l}\mathrm{C} \\
\mathrm{O}_{0-11} \\
\mathrm{O}_{12-21} \\
\mathrm{H}_{0-11} \\
\mathrm{H}_{12-21} \\
\text { SEM }\end{array}$ & $\begin{array}{l}0.305 \\
0.320 \\
0.311 \\
0.329 \\
0.319 \\
0.02\end{array}$ & $\begin{array}{l}1.90 \\
2.10 \\
1.99 \\
2.24 \\
1.92 \\
0.13\end{array}$ & $\begin{array}{l}0.49 \\
0.46 \\
0.48 \\
0.50 \\
0.50 \\
0.02\end{array}$ & $\begin{array}{l}2.98 \\
3.00 \\
3.10 \\
3.34 \\
3.02 \\
0.10\end{array}$ & $\begin{array}{l}0.47^{\mathrm{a}} \\
0.39^{\mathrm{b}} \\
0.43^{\mathrm{ab}} \\
0.43^{\mathrm{ab}} \\
0.44^{\mathrm{ab}} \\
0.02\end{array}$ & $\begin{array}{l}2.89 \\
2.57 \\
2.74 \\
2.87 \\
2.69 \\
0.14\end{array}$ & $\begin{array}{l}0.018 \\
0.014 \\
0.019 \\
0.015 \\
0.014 \\
0.002\end{array}$ & $\begin{array}{l}0.11 \\
0.08 \\
0.12 \\
0.10 \\
0.08 \\
0.03\end{array}$ & $\begin{array}{l}0.017 \\
0.017 \\
0.017 \\
0.015 \\
0.016 \\
0.05\end{array}$ & $\begin{array}{l}1.05 \\
1.12 \\
1.27 \\
1.02 \\
0.98 \\
0.28\end{array}$ & $\begin{array}{l}- \\
- \\
- \\
- \\
- \\
-\end{array}$ & $\begin{array}{l}- \\
- \\
- \\
-\end{array}$ \\
\hline 17 & $\begin{array}{l}\mathrm{C} \\
\mathrm{O}_{0-11} \\
\mathrm{O}_{12-21} \\
\mathrm{H}_{0-11} \\
\mathrm{H}_{12-21} \\
\text { SEM }\end{array}$ & $\begin{array}{l}0.47 \\
0.51 \\
0.48 \\
0.45 \\
0.52 \\
0.03\end{array}$ & $\begin{array}{l}2.16^{\mathrm{ab}} \\
2.43^{\mathrm{ab}} \\
1.99^{\mathrm{b}} \\
2.22^{\mathrm{ab}} \\
2.63^{\mathrm{a}} \\
0.18\end{array}$ & $\begin{array}{l}0.61 \\
0.61 \\
0.57 \\
0.61 \\
0.51 \\
0.05\end{array}$ & $\begin{array}{l}2.76^{\mathrm{ab}} \\
2.93^{\mathrm{ab}} \\
2.41^{\mathrm{b}} \\
3.08^{\mathrm{a}} \\
2.27^{\mathrm{b}} \\
0.22\end{array}$ & $\begin{array}{l}0.71 \\
0.63 \\
0.76 \\
0.74 \\
0.67 \\
0.04\end{array}$ & $\begin{array}{l}3.18^{\mathrm{ab}} \\
3.03^{\mathrm{b}} \\
3.18^{\mathrm{ab}} \\
3.67^{\mathrm{a}} \\
3.19^{\mathrm{ab}} \\
0.81\end{array}$ & $\begin{array}{l}0.19^{\mathrm{ab}} \\
0.20^{\mathrm{a}} \\
0.20^{\mathrm{a}} \\
0.16^{\mathrm{bc}} \\
0.15^{\mathrm{c}} \\
0.04\end{array}$ & $\begin{array}{l}0.89^{\mathrm{ab}} \\
0.94^{\mathrm{a}} \\
0.85^{\mathrm{ab}} \\
0.82^{\mathrm{ab}} \\
0.73^{\mathrm{b}} \\
0.20\end{array}$ & $\begin{array}{l}0.017 \\
0.026 \\
0.024 \\
0.017 \\
0.021 \\
0.04\end{array}$ & $\begin{array}{l}0.08 \\
0.12 \\
0.10 \\
0.09 \\
0.12 \\
0.03\end{array}$ & $\begin{array}{l}0.010 \\
0.012 \\
0.011 \\
0.012 \\
0.010 \\
0.001\end{array}$ & $\begin{array}{l}0.045 \\
0.059 \\
0.049 \\
0.059 \\
0.051 \\
0.007\end{array}$ \\
\hline 19 & $\begin{array}{l}\mathrm{C} \\
\mathrm{O}_{0-11} \\
\mathrm{O}_{12-21} \\
\mathrm{O}_{18-21} \\
\mathrm{H}_{0-11} \\
\mathrm{H}_{12-21} \\
\mathrm{H}_{18-21} \\
\mathrm{SEM}\end{array}$ & $\begin{array}{l}0.61 \\
0.57 \\
0.62 \\
0.59 \\
0.60 \\
0.58 \\
0.58 \\
0.01\end{array}$ & $\begin{array}{l}2.04 \\
2.02 \\
1.99 \\
1.83 \\
2.03 \\
1.93 \\
2.00 \\
0.04\end{array}$ & $\begin{array}{l}0.83^{\mathrm{a}} \\
0.74^{\mathrm{bc}} \\
0.73^{\mathrm{bc}} \\
0.79^{\mathrm{ab}} \\
0.68^{\mathrm{c}} \\
0.80^{\mathrm{ab}} \\
0.72^{\mathrm{bc}} \\
0.02\end{array}$ & $\begin{array}{l}2.80^{\mathrm{a}} \\
2.62^{\mathrm{ab}} \\
2.31^{\mathrm{bc}} \\
2.46^{\mathrm{abc}} \\
2.10^{\mathrm{c}} \\
2.67^{\mathrm{a}} \\
2.51^{a b c} \\
0.05\end{array}$ & $\begin{array}{l}1.07^{\mathrm{ab}} \\
1.01^{\mathrm{b}} \\
1.16^{\mathrm{a}} \\
1.18^{\mathrm{a}} \\
1.12^{\mathrm{ab}} \\
1.16^{\mathrm{a}} \\
1.09^{\mathrm{ab}} \\
0.03\end{array}$ & $\begin{array}{l}3.62 \\
3.57 \\
3.66 \\
3.66 \\
3.89 \\
3.89 \\
3.74 \\
0.07\end{array}$ & $\begin{array}{l}0.26 \\
0.24 \\
0.24 \\
0.29 \\
0.28 \\
0.26 \\
0.22 \\
0.02\end{array}$ & $\begin{array}{l}0.88 \\
0.84 \\
0.76 \\
0.89 \\
1.09 \\
0.87 \\
0.76 \\
0.05\end{array}$ & $\begin{array}{l}0.04^{\mathrm{a}} \\
0.02^{\mathrm{b}} \\
0.03^{\mathrm{ab}} \\
0.04^{\mathrm{a}} \\
0.02^{\mathrm{ab}} \\
0.03^{\mathrm{ab}} \\
0.03^{\mathrm{ab}} \\
0.01\end{array}$ & $\begin{array}{l}0.10^{\mathrm{a}} \\
0.06^{\mathrm{b}} \\
0.09^{\mathrm{ab}} \\
0.09^{\mathrm{ab}} \\
0.09^{\mathrm{ab}} \\
0.09^{\mathrm{ab}} \\
0.08^{\mathrm{ab}} \\
0.04\end{array}$ & $\begin{array}{l}0.008^{\mathrm{ab}} \\
0.009^{\mathrm{ab}} \\
0.010^{\mathrm{ab}} \\
0.009^{\mathrm{ab}} \\
0.007^{\mathrm{b}} \\
0.011^{\mathrm{a}} \\
0.009^{\mathrm{ab}} \\
0.00\end{array}$ & $\begin{array}{r}0.028 \\
0.031 \\
0.031 \\
0.029 \\
0.026 \\
0.038 \\
0.031 \\
0.01\end{array}$ \\
\hline Hatch & $\begin{array}{l}\mathrm{C} \\
\mathrm{O}_{0-11} \\
\mathrm{O}_{12-21} \\
\mathrm{O}_{18-21} \\
\mathrm{H}_{0-11} \\
\mathrm{H}_{12-21} \\
\mathrm{H}_{18-21} \\
\mathrm{SEM}\end{array}$ & $\begin{array}{l}0.95^{\mathrm{ab}} \\
0.95^{\mathrm{ab}} \\
1.03^{\mathrm{ab}} \\
1.05^{\mathrm{a}} \\
0.91^{\mathrm{b}} \\
0.95^{\mathrm{ab}} \\
1.05^{\mathrm{a}} \\
0.01\end{array}$ & $\begin{array}{l}2.09^{\mathrm{ab}} \\
2.05^{\mathrm{b}} \\
2.29^{\mathrm{ab}} \\
2.34^{\mathrm{a}} \\
2.05^{\mathrm{b}} \\
2.13^{\mathrm{ab}} \\
2.33^{\mathrm{a}} \\
0.03\end{array}$ & $\begin{array}{l}0.74^{\mathrm{ab}} \\
0.80^{\mathrm{a}} \\
0.73^{\mathrm{ab}} \\
0.77^{\mathrm{ab}} \\
0.62^{\mathrm{b}} \\
0.75^{\mathrm{ab}} \\
0.78^{\mathrm{a}} \\
0.01\end{array}$ & $\begin{array}{l}1.63 \\
1.72 \\
1.60 \\
1.71 \\
1.43 \\
1.69 \\
1.73 \\
0.05\end{array}$ & $\begin{array}{l}2.27^{\mathrm{ab}} \\
2.13^{\mathrm{bc}} \\
2.37^{\mathrm{a}} \\
2.36^{\mathrm{a}} \\
2.03^{\mathrm{c}} \\
2.04^{\mathrm{c}} \\
2.23^{\mathrm{abc}} \\
0.02\end{array}$ & $\begin{array}{l}5.01^{\mathrm{ab}} \\
4.59^{\mathrm{b}} \\
5.27^{\mathrm{a}} \\
5.26^{\mathrm{a}} \\
4.57^{\mathrm{b}} \\
4.57^{\mathrm{b}} \\
4.94^{\mathrm{ab}} \\
0.06\end{array}$ & $\begin{array}{l}0.25^{\mathrm{ab}} \\
0.21^{\mathrm{b}} \\
0.20^{\mathrm{b}} \\
0.24^{\mathrm{ab}} \\
0.30^{\mathrm{ab}} \\
0.24^{\mathrm{ab}} \\
0.39^{\mathrm{a}} \\
0.02\end{array}$ & $\begin{array}{l}0.55^{\mathrm{ab}} \\
0.45^{\mathrm{b}} \\
0.44^{\mathrm{b}} \\
0.55^{\mathrm{ab}} \\
0.68^{\mathrm{ab}} \\
0.53^{\mathrm{ab}} \\
0.86^{\mathrm{a}} \\
0.04\end{array}$ & $\begin{array}{l}0.24^{\mathrm{b}} \\
0.21^{\mathrm{b}} \\
0.21^{\mathrm{b}} \\
0.24^{\mathrm{b}} \\
0.14^{\mathrm{c}} \\
0.25^{\mathrm{b}} \\
0.36^{\mathrm{a}} \\
0.02\end{array}$ & $\begin{array}{l}0.52^{\mathrm{ab}} \\
0.45^{\mathrm{b}} \\
0.46^{\mathrm{b}} \\
0.44^{\mathrm{b}} \\
0.54^{\mathrm{a}} \\
0.33^{\mathrm{c}} \\
0.55^{\mathrm{a}} \\
0.03\end{array}$ & $\begin{array}{l}0.013 \\
0.011 \\
0.016 \\
0.017 \\
0.015 \\
0.013 \\
0.012 \\
0.00\end{array}$ & $\begin{array}{r}0.028 \\
0.024 \\
0.035 \\
0.038 \\
0.035 \\
0.030 \\
0.026 \\
0.01\end{array}$ \\
\hline$P$ value & $\begin{array}{l}\text { IC } \\
\text { Age } \\
\text { IC } \times \text { Age }\end{array}$ & $\begin{array}{l}0.478 \\
<0.001 \\
0.682\end{array}$ & $\begin{array}{l}0.669 \\
<0.001 \\
0.085\end{array}$ & $\begin{array}{l}0.504 \\
<0.001 \\
0.472\end{array}$ & $\begin{array}{l}0.149 \\
<0.001 \\
0.009\end{array}$ & $\begin{array}{l}0.034 \\
<0.001 \\
0.005\end{array}$ & $\begin{array}{l}0.033 \\
<0.001 \\
0.024\end{array}$ & $\begin{array}{l}0.957 \\
<0.001 \\
0.925\end{array}$ & $\begin{array}{l}0.286 \\
<0.001 \\
0.205\end{array}$ & $\begin{array}{l}0.547 \\
<0.001 \\
0.697\end{array}$ & $\begin{array}{l}0.359 \\
<0.001 \\
0.192\end{array}$ & $\begin{array}{l}0.808 \\
0.022 \\
0.721\end{array}$ & $\begin{array}{l}0.685 \\
0.001 \\
0.725\end{array}$ \\
\hline
\end{tabular}

${ }^{\mathrm{a}-\mathrm{c}}$ Means within a column for each of embryonic age with different superscript differ significantly at $P<0.05$.

${ }^{\mathrm{d}} \mathrm{C}$ : control, $\mathrm{O}_{0-11}: 23.5 \% \mathrm{O}_{2}$ supplementation between days 0 and 11 of incubation, $\mathrm{O}_{12-21}: 23.5 \% \mathrm{O}_{2}$ supplementation between days 12 and 21 of incubation, $\mathrm{O}_{18-21}: 23.5 \% \mathrm{O}_{2}$ supplementation between days 18 and 21 of incubation, $\mathrm{H}_{0-11}: 38.5^{\circ} \mathrm{C}$ high incubation temperature between days 0 and 11 of incubation, $\mathrm{H}_{12-21}: 38.5^{\circ} \mathrm{C}$ high incubation temperature between days 12 and 21 of incubation, $\mathrm{H}_{18-21}$ :

$38.5^{\circ} \mathrm{C}$ high incubation temperature between days 18 and 21 of incubation. SEM: standard error means.

ing the physiological status of the embryo at day 7 of incubation, it may be concluded that an epigenetic change occurs in response to heat manipulation because this treatment group compared with all of the other treatment groups had the highest eggshell temperature at days $13,15,17$, and 19 of incubation. The developmental stage-related heat production of the chicken embryo gradually increases from days 9 to 16 and then reaches a plateau phase from days 17 to 19. Janke et al. (2004) demonstrated different heat production rates at different developmental stages of embryo. The increased eggshell temperature in $\mathrm{H}$ administration at an early embry- onic stage can be increased by the rate of heat production, controlled by the central nervous system, as heat production is linearly related to eggshell temperature and may limit embryo development at $38.9^{\circ} \mathrm{C}$ (Lourens et al., 2006). Interestingly, the highest eggshell temperature by $\mathrm{H}$ treatment at an early incubation stage (days from 0 to 11 of incubation) resulted in the lowest rectal temperature in newly hatched chicks, which may be due to a decreased thermoregulatory set point of chicks (Tzschentke and Nichelmann, 1999). The present study has demonstrated that broiler embryos exposed to $\mathrm{H}$ treatment at an early embryonic stage did not develop 
Table 6. Effects of incubation conditions and sex on blood parameters induced by hypoxia at high altitude for newly hatched chicks.

\begin{tabular}{|c|c|c|c|c|c|c|}
\hline & & $\begin{array}{l}\mathrm{T}_{3} \\
\mathrm{ng} \mathrm{mL}-1\end{array}$ & $\begin{array}{l}\mathrm{T}_{4} \\
\mathrm{ng} \mathrm{mL}-1\end{array}$ & $\mathrm{~T}_{3} / \mathrm{T}_{4}$ & $\begin{array}{l}\text { Hemoglobin } \\
\mathrm{g} \mathrm{dL}^{-1}\end{array}$ & $\begin{array}{l}\text { Hematocrit } \\
\%\end{array}$ \\
\hline \multirow{8}{*}{$\begin{array}{l}\text { Incubation } \\
\text { conditions, } \\
\text { IC }^{d}\end{array}$} & $\mathrm{C}$ & $0.51^{\mathrm{c}}$ & $5.58^{\mathrm{bc}}$ & $0.098^{\mathrm{ab}}$ & $11.40^{\mathrm{a}}$ & $36.11^{\mathrm{c}}$ \\
\hline & $\mathrm{O}_{0-11}$ & $0.48^{\mathrm{c}}$ & $6.91^{\mathrm{a}}$ & $0.063^{b}$ & $9.35^{\mathrm{c}}$ & $36.70^{\mathrm{bc}}$ \\
\hline & $\mathrm{O}_{12-21}$ & $0.78^{\mathrm{a}}$ & $6.94^{\mathrm{a}}$ & $0.112^{\mathrm{a}}$ & $8.57^{\mathrm{d}}$ & $32.00^{\mathrm{d}}$ \\
\hline & $\mathrm{O}_{18-21}$ & $0.46^{\mathrm{c}}$ & $5.27^{\mathrm{c}}$ & $0.090^{\mathrm{ab}}$ & $10.65^{\mathrm{b}}$ & $38.40^{\mathrm{bc}}$ \\
\hline & $\mathrm{H}_{0-11}$ & $0.81^{\mathrm{a}}$ & $7.86^{\mathrm{a}}$ & $0.103^{\mathrm{ab}}$ & $9.01^{c d}$ & $37.77^{\mathrm{bc}}$ \\
\hline & $\mathrm{H}_{12-21}$ & $0.63^{\mathrm{b}}$ & $6.21^{\mathrm{ab}}$ & $0.110^{\mathrm{a}}$ & $12.62^{\mathrm{a}}$ & $43.03^{\mathrm{a}}$ \\
\hline & $\mathrm{H}_{18-21}$ & $0.75^{\mathrm{ab}}$ & $7.19^{\mathrm{a}}$ & $0.106^{\mathrm{a}}$ & $11.49^{\mathrm{a}}$ & $39.49^{a b}$ \\
\hline & SEM & 0.04 & 0.58 & 0.007 & 0.43 & 1.64 \\
\hline \multirow[t]{3}{*}{ Sex } & Female & 0.62 & $6.04^{b}$ & 0.101 & 10.69 & 37.82 \\
\hline & Male & 0.63 & $7.08^{\mathrm{a}}$ & 0.094 & 10.66 & 37.47 \\
\hline & SEM & 0.03 & 0.32 & 0.005 & 0.31 & 1.27 \\
\hline \multirow[t]{3}{*}{$P$ value } & IC & $<0.001$ & 0.012 & 0.003 & 0.026 & 0.048 \\
\hline & Sex & 0.152 & 0.026 & 0.364 & 0.939 & 0.850 \\
\hline & $\mathrm{IC} \times \mathrm{Sex}$ & 0.799 & 0.718 & 0.196 & 0.233 & 0.939 \\
\hline
\end{tabular}

a-d Means within a column with different superscript differ significantly at $P<0.05$.

${ }^{\mathrm{d}} \mathrm{C}$ : control, $\mathrm{O}_{0-11}: 23.5 \% \mathrm{O}_{2}$ supplementation between days 0 and 11 of incubation, $\mathrm{O}_{12-21}: 23.5 \% \mathrm{O}_{2}$ supplementation between days 12 and 21 of incubation, $\mathrm{O}_{18-21}: 23.5 \% \mathrm{O}_{2}$ supplementation between days 18 and 21 of incubation, $\mathrm{H}_{0-11}: 38.5^{\circ} \mathrm{C}$ high incubation temperature between days 0 and 11 of incubation, $\mathrm{H}_{12-21}: 38.5^{\circ} \mathrm{C}$ high incubation temperature between days 12 and 21 of incubation, $\mathrm{H}_{18-21}: 38.5^{\circ} \mathrm{C}$ high incubation temperature between

days 18 and 21 of incubation. SEM: standard error means.

resistance to high temperature during the early embryonic stage when eggs from sea level were incubated in hypoxia caused by $1720 \mathrm{~m}$ altitude. On the other hand, Bahadoran et al. (2010) indicated that hypoxia due to HA during early embryogenesis may change the endocrine functions of the embryo, enhance embryo growth, or shorten the hatching process of chickens. However, early $\mathrm{H}$ treatment at hypoxic HA resulted in an increased egg water loss at day 11 of incubation. This excessive water loss resulted in increased embryonic mortalities, obtaining the worst hatchability. At an early incubation period, the resulting effects due to a combination of high temperature and hypoxic HA indicated that the chick's thermal-tolerance acquisition did not improve and negatively affected all examined traits. However, at $1720 \mathrm{~m}$ altitude, the best hatchability was obtained when incubated hatching eggs from sea level were treated with middle and late $\mathrm{O}_{2}$ supplementation to incubators. The best hatchability could be related to a decrease in egg water loss resulted in the lowest eggshell temperature on days 15 and 17 of incubation in $\mathrm{O}_{2}$ supplementation to incubator at the middle embryogenesis stage, whereas this treatment had the highest rectal temperature. Due to adaptability to hypoxia, supplemental $\mathrm{O}_{2}$ is a good way to improve hatchability and chick quality. Zhang et al. (2008) indicated that breeding chickens adapted to HA (a $2900 \mathrm{~m}$ altitude) had a lower egg water loss and greater hatchability when they were incubated in hypoxic conditions. The findings of this study indicated that $\mathrm{O}_{2}$ supplementation to the incubator after middle to last stages of embryogenesis could increase hatchability and decrease embryonic mortality because of the lowest egg water loss. This phenomenon was confirmed by the findings reported by Lourens (2008), who had shown that eggs require different IC conditions for maximum hatchability.

Oxygen treatment at an early stage of incubation resulted in decreased embryonic development until day 15 of incubation, but $\mathrm{O}$ treatment at the middle stage of incubation led to the highest embryo weight on day 17 of incubation in the current study. Oxygen treatment at the middle stage of incubation relative to other incubation stages could improve the embryo weight relative to the sensitivity of embryos to hypoxia. This was explained by Dzialowski et al. (2002), who reported that chicken embryos are most sensitive to hypoxia during the middle-third period of incubation relative to the early- or late periods of incubation. At hypoxic HA, IC treatments relative to the control did not affect the absolute and relative embryo or chick weights at days 19 of incubation at hatching. However, when incubated at HA, eggs from sea level had a depressive effect on embryo growth at day 20 of incubation due to decreased uptake of yolk resources (Giussani et al., 2007). The different conclusions on development may be related to the timing of IC exposure in hypoxia caused by HA, which plays a role in the development of embryos and newly hatched chicks. The results indicated that developmental stages of broiler embryos on development are important to the timing of $\mathrm{O}_{2}$ exposure at hypoxic HA during incubation. The highest yolk sac weight was in the $\mathrm{O}$ treatment groups applied early, middle, or late in development, especially on day 17 of incubation, which indicated lower yolk 
sac utilization, but this situation was reversed by $\mathrm{O}$ treatment in embryos at day 19 of incubation, when it can require more uptake of energy as respiratory muscle activity for metabolic energy consumption because the embryo prepares for pulmonary respiration and hatching (Tickle et al., 2014). Under hypoxia, changes in lung function enhance the transition to pulmonary respiration and to ensure early hatching (Onagbesan et al., 2007). At hypoxia due to a $1720 \mathrm{~m}$ altitude, early hatching was also observed by Güler and Babacanoğlu (2017), who concluded that shorter external pipping and total incubation durations at hypoxia were due to HA. On day 17 of incubation, the weight of lung increased in $\mathrm{O}_{2}$ treatment rather than in $\mathrm{H}$ treatment at the middle period of incubation at hypoxic $\mathrm{HA}$. This was because $\mathrm{O}_{2}$ supplementation $\left(23.5 \% \mathrm{O}_{2}\right)$ to meet the required metabolic energy need of broiler embryos resulted in an increase in the lung development at hypoxic HA. Liver weight increased in $\mathrm{H}$ treatment relative to $\mathrm{O}$ treatment from days 12 to the end of incubation. This showed that metabolic activity of the embryo was affected differently by $\mathrm{O}_{2}$ or heat exposure during this embryogenesis stage at hypoxic HA. A similar result was also reported at normoxia ( $2 \mathrm{~m}$ altitude), with increased liver weight by heat acclimation for 5 days after day 12 of incubation (Babacanoğlu et al., 2006). Lourens (2008) indicated that deviations from $37.8^{\circ} \mathrm{C}$ in the first or third week of incubation depressed embryo development. However, in this study, only the $\mathrm{H}$ treatment at an early stage of incubation was effective to depress embryonic development. Interestingly, the depression in $\mathrm{H}$ treatment at an early stage was not observed at hatching. Before hatching, the depressed development of embryos from $\mathrm{H}$ treatment at an early stage of incubation may have been responsible for the lower yolk sac absorption. Conversely, it was concluded that higher yolk sac uptake of embryos from $\mathrm{H}$ treatment at the middle embryonic stage on day 17 of incubation, though chick development was not affected. This result was similar to the conclusions obtained by long-term high incubation temperature $\left(38.8^{\circ} \mathrm{C}\right)$ from day 12 to the end of incubation resulting in reduced yolk consumption of embryos (Ozaydın and Celik, 2014). At normoxia, high incubation temperature accelerates chick weight exposed to $39.6^{\circ} \mathrm{C}$ for $6 \mathrm{~h}$ daily from 10 to 18 days of incubation (Yalçın et al., 2008), whereas high incubation temperature at hypoxic HA had no effect on chick weight in the current study. Similarly, Iqbal et al. (1990) reported that no differences in the weights of chicks from eggs incubated in optimum conditions or exposed to $39.0^{\circ} \mathrm{C}$ for $6 \mathrm{~h}$ daily from 11 to 20 days of incubation.

In this study, the ratio of $T_{3} / T_{4}$ was observed similar among IC treatments at hypoxic HA, similar to the results reported by de Souza Morita et al. (2016), who showed that exposure to high incubation temperature may be an effective factor in their adaptation to environmental conditions at the post-hatch stage without changes in thyroid hormones of broiler chicks. At hypoxia due to HA, as the embryo prepares for its post-hatch life, significant changes are ensured by controlled physiological changes that coordinate the marked changes (De Oliveira et al., 2008). The marked changes occur as physiological changes by metabolic hormone profiles during embryo development (Lu et al., 2007). The chicks from the $\mathrm{H}$ treatments had higher serum $\mathrm{T}_{3}$ and $\mathrm{T}_{4}$ concentrations, which is a sign of the highest heat production rate compared to control chicks. Thyroid hormones are primarily involved in energy production by increasing metabolic rate; heat production is especially regulated with these hormones (Mcnabb, 2000). In this study, the effect of early and late $\mathrm{H}$ treatments on thyroid hormones resulted in an increase that can be explained by an alteration at the post-hatch thermoregulatory system inducing epigenetic adaptation by significant changes in these metabolic hormones at hatching. Obtained higher serum $\mathrm{T}_{4}$ concentration in the newly hatched male chicks in this study was due to higher development dependent on a decreased basal arterial blood pressure (Herrera et al., 2013), and enhanced pulmonary artery diameter (Salinas et al., 2014), where thyroid hormone activity caused by rapid growth related to lung development (Hassanzadeh et al., 2008) rather than female broiler chicks.

Thyroid hormones act on the brain development of chick embryos (Giguere et al., 1996) because thyroid hormones as regulatory factors are responsible for differentiation, maturation, and growth of the tissues in the pre- and post-hatch development (Mcnabb and Wilson, 1997). The brain development of embryos from $\mathrm{O}$ treatment at the middle embryonic stage and from $\mathrm{H}$ treatment at the early embryonic stage decreased at internal pipping because $\mathrm{T}_{3}$ and $\mathrm{T}_{4}$ concentrations increased in these treatments of the study. Higher $\mathrm{T}_{3}$ and $\mathrm{T}_{4}$ serum concentrations and the ratio of $\mathrm{T}_{3} / \mathrm{T}_{4}$, as well as lower blood hemoglobin and hematocrit levels in newly hatched chicks from $\mathrm{O}$ treatment from days 12 to 21 of incubation at hypoxic HA, may be able to accelerate metabolism and to carry more $\mathrm{O}_{2}$ to cells from blood to recover physiologically $\mathrm{O}_{2}$ homeostasis based on epigenetic changes (Perez-Perri et al., 2011).

Plasma $T_{3}$ and $T_{4}$ concentrations increased from days 18 to 21 of incubation as concluded by Darras et al. (1994), but lower serum $\mathrm{T}_{3}$ and $\mathrm{T}_{4}$ concentrations by $\mathrm{O}$ supplementation towards the end of incubation may be related to increased hemoglobin concentration because higher blood hemoglobin concentration was found in the treated embryos than control and $\mathrm{H}$ embryos at the middle and late periods of embryogenesis. The $\mathrm{H}$ treatment at the middle and late embryogenesis stages may cause the high hematocrit concentration to increase hemoglobin at hypoxic HA during the pre-hatch period because high hematocrit appears less susceptible to stress effects by maintaining leukocytes at a constant level in broilers (McWilliams, 2008). Additionally, this study has shown a decreased hemoglobin concentration, which was observed in the same result in newly hatched chicks from the $\mathrm{O}$ treated group, through the release of red blood cells from storage sites. The relative bursa of fabricius development decrease in the $\mathrm{H}$ treatment at the middle embryonic stage 
may be explained by the findings reported as the metabolic demands of the developing embryo led to tissue hypoxia (Druyan et al., 2007). Tissue hypoxia in the bursa of fabricius of treated groups was likely the reason for genes expressed at day 7 of incubation in the chick embryo, such as tissuespecific hypoxia for the HIF1 gene induction.

The heart weight from $\mathrm{O}$ treated embryos at middle embryonic stages on day 17 of incubation and heart weight of embryos from $\mathrm{O}$ treatment of middle and late embryonic stages at hatching increased related to the findings of examined parameters, which were the weights of RV, LV + septum and TV in the study. Zhang and Burggren (2012) reported that only the heart weight was found to be differentially stimulated by hypoxia among the measured internal organs of the embryo, and authors concluded that hypoxia had highly differential effects on embryonic development, depending on the level and timing of hypoxia. For example, its occurrence early during incubation (first 10 days) has larger effects on embryonic mortality and organ growth than hypoxia occurring at later stages (days from 10 to 18). The nonhypertrophic RV : TV ratio changed by 0.19 and 0.20 for the $\mathrm{O}$ groups during pre-hatch at hypoxic HA, suggesting a low incidence of ascites syndrome when reared of broiler chicks from the $\mathrm{O}$ groups, as an $\mathrm{RV}$ : TV ratio over 0.25 was not observed (Gonzales et al., 1998). Hassanzadeh et al. (2004) recommended the investigation of the connection between IC and processes involved in the development of ascites. The connection by means of physiological functions can be altered with IC, especially by $\mathrm{O}$ treatments at hypoxic HA. Ascites susceptibility may be decreased by developmental and endocrine changes by the influence of $\mathrm{O}$ treatment at middle and late stages of embryonic development at hypoxic HA. Such changes may be related to physiological responses to provide adaptation to hypoxic $\mathrm{HA}$ and to meet elevated $\mathrm{O}_{2}$ demand by the cardiovascular system in broilers. Physiological alterations of broiler embryo from $\mathrm{O}_{2}$ supplementation and $\mathrm{H}$ affected adaptation to hypoxic $\mathrm{HA}$ can be confirmed with unchanged absolute and relative weights of spleen.

The study has concluded that depending on the timing of IC exposure, eggs obtained from broiler breeders at sea level can be evaluated for a more effective treatment of $\mathrm{O}$ that positively affects changes in the physiological system, especially after half of the incubation, or $\mathrm{H}$ can be a long-term epigenetic force, effecting changes in physiological traits of the broiler embryo during the pre-hatch period at hypoxic HA.

Data availability. The available data set of the present study was used.

Competing interests. The author declares that there is no conflict of interest.
Acknowledgements. All procedures were approved by Van Yuzuncu Yil University, Animal Care and Use Committee (permit number 2016-04). The study was funded by Van Yuzuncu Yil University, Scientific Research Projects Coordinator.

Edited by: Manfred Mielenz

Reviewed by: two anonymous referees

\section{References}

Albers, G. and Frankenhuis, M.T.: Ascites, a high altitude disease in the lowlands, Poultry, 6, 24-25, 1990.

Babacanoğlu, E. and Güler, H. C.: High temperature and oxygen supplementation can mitigate the effects of hypoxia on developmental stability of bilateral traits during incubation of broiler breeder eggs, Animal, 12, 1584-1593, https://doi.org/10.1017/S1751731118000344, 2018.

Babacanoğlu, E., Güler, H. C., and Yalçin, S.: Effect of timing of acclimation of broiler breeder eggs during incubation on embryo and chick development, in: XII European Poultry Conference, Verona, Italy, 10-14 September 2010, p. 482, 2006.

Bahadoran, S., Hassanzadeh, M., and Zamanimoghaddam, A. K.: Effect of chronic hypoxia during the early stage of incubation on prenatal and postnatal parameters related to ascites syndrome in broiler chickens, Iran. J. Vet. Res., 11, 64-71, 2010.

Burggren, W. W. and Elmonoufy, N. A.: Critical developmental windows for morphology and hematology revealed by intermittent and continuous hypoxic incubation in embryos of quail (Coturnix coturnix) PloS ONE, 12, e0183649, https://doi.org/10.1371/journal.pone.0183649, 2017.

Carreau, A., Hafny Rahbi, B. E., Matejuk, A., Grillon, C., and Kieda, C.: Why is the partial oxygen pressure of human tissues a crucial parameter? Small molecules and hypoxia, J. Cell. Mol. Med., 15, 1239-1253, 2011.

Darras, V. M., Kühn, E. R., and Decuypere, E.: Comperative aspects of maturation and control of thyroid hormone deiodination during development, Isr. J. Zool., 40, 383-400, 1994.

Dawson, W. R. and Whittow, G. C.: Regulation of body temperature, chap. 14, in: Sturkie's Avian Physiology, 5th edn., edited by: Whittow, G. C., Academic Press, New York, 461-469, 2000.

Decuypere, E. and Bruggeman, V.: The endocrine interface of environmental and egg factors affecting chick quality, Poultry Sci., 86, 1037-1042, 2007.

Decuypere, E., Van As, P., Van der Geyten, S., and Darras, V. M.: Thyroid hormone availability and activity in avian species: A review, Domest. Anim. Endocrin., 29, 63-77, 2005.

De Oliveira, J. E., Uni, Z., and Ferket, P. R.: Important metabolic pathways in poultry embryos prior to hatch, World. Poultry Sci. J., 64, 488-499, 2008.

de Souza Morita, V., De Almeida, V. R., Junior, J. B. M., Vicentini, T. I., van den Brand, H., and Boleli, I. C.: Incubation temperature during fetal development influences morphophysiological characteristics and preferred ambient temperature of chicken hatchlings, PloS ONE, 11, e0154928, https://doi.org/10.1371/journal.pone.0154928, 2016.

Druyan, S., Cahaner, A. and Ashwell, C. M.: The expression patterns of hypoxia-inducing factor subunit $\alpha-1$, heme oxygenase, hypoxia upregulated protein 1 , and cardiac troponin $\mathrm{T}$ during 
development of the chicken heart, Poultry Sci., 86, 2384-2389, 2007.

Dzialowski, E. M., Von Plettenberg, D., Elmonoufy, N. A., and Burggren, W. W.: Chronic hypoxia alters the physiological and morphological trajectories of developing chicken embryos, Comp. Biochem. Physiol. A, 131, 713-724, 2002.

Giguere, A., Fortier, S., Beaudry, C., Gallo-Payet, N., and Bellabarba, D.: Effect of thyroid hormones on $G$ proteins in synaptosomes of chick embryo, Endocrinology, 137, 2558-2564, 1996.

Giussani, D. A., Salinas, C. E., Villena, M., and Blanco, C. E.: The role of oxygen in prenatal growth: studies in the chick embryo, J. Physiol., 585, 911-917, 2007.

Gonzales, E., Buyse, J., Takita, T. S., and Decuypere, E.: Metabolic disturbances in male broilers of different strains. 1. Performance, mortality, and right ventricular hypertrophy, Poultry Sci., 77, 1646-1653, 1998.

Güler, H. C. and Babacanoğlu E.: Impact of oxygen supplementation and alternative temperature application on hatchability and total incubation time high altitude, in: Proceeding of 4th International Poultry Meat Congress, Antalya, Turkey, 26-30 April 2017, 110-116, 2017.

Hassanzadeh, M., Buyse, J., and Decuypere, E.: Relationship between myocardial $\beta$-adrenergic receptor characteristics and the incidence of ascites in broiler chickens, Avian Pathol., 30, 169174, 2001.

Hassanzadeh, M., Fard, M. B., Buyse, J., Bruggeman, V., and Decuypere, E.: Effect of chronic hypoxia during embryonic development on physiological functioning and on hatching and posthatching parameters related to ascites syndrome in broiler chickens, Avian Pathol., 33, 558-564, 2004.

Hassanzadeh, M., Buyse, J., and Decuypere, E.: Further evidence for the involvement of anatomical parameters of cardiopulmonary system in the development of ascites syndrome in broiler chickens, Acta Vet. Hung., 71, 71-80, 2008.

Herrera, E. A., Salinas, C. E., Blanco, C. E., Vilena, M., and Giussani, D.: A High altitude hypoxia and blood pressure dysregulation in aldut chickens, J. Dev. Orig. Hlth. Dis., 4, 69-76, 2013.

Iqbal, A., Decuypere, E., El Azim, A. A., and Kühn, E. R.: Preand post-hatch high temperature exposure affects the thyroid hormones and corticosterone response to acute heat stress in growing chicken (Gallus domesticus), J. Therm. Biol., 15, 149-153, 1990.

Janke, O., Tzschentke, B., and Boerjan, M.: Comparative investigations of heat production and body temperature in embryos of modern chicken breeds, Avian Poul. Biol. Rev., 15, 191-196, 2004.

Julian, R. J.: The effect of increased sodium in the drinking water on right ventricular hypertrophy, right ventricular failure and ascites in broiler chickens, Avian Pathol., 16, 61-71, 1987.

Julian, R. J.: Physiological, management and environmental triggers of the ascites syndrome: a review, Avian Pathol., 29, 519-527, 2000.

Khajali, F. and Wideman, R. F.: Nutritional approaches to ameliorate pulmonary hypertension in broiler chickens, J. Anim. Physiol. An. N., 100, 3-14, 2016.

Lorenzoni, A. G. and Ruiz-Feria, C. A.: Effects of vitamin E and L-arginine on cardiopulmonary function and ascites parameters in broiler chickens reared under subnormal temperatures, Poultry Sci., 85, 2241-2250, 2006.

Lourens, A.: Embryo temperature during incubation: Practice and theory, PhD thesis, Wageningen University, The Netherlands, 2008.

Lourens, A., Van den Brand, H., Meijerhof, R., and Kemp, B.: Effect of eggshell temperature during incubation on embryo development, hatchability, and posthatch development, Poultry Sci., 84, 914-920, 2005.

Lourens, A., Molenaar, R., van den Brand, H., Heetkamp, M. J. W., Meijerhof, R., and Kemp, B.: Effect of egg size on heat production and the transition of energy from egg to hatchling, Poultry Sci., 85, 770-776, 2006.

Lourens, A., Van den Brand, H., Heetkamp, M. J. W., Meijerhof, R., and Kemp, B.: Effects of eggshell temperature and oxygen concentration on embryo growth and metabolism during incubation, Poultry Sci., 86, 2194-2199, 2007.

Lu, J. W., McMurtry, J. P., and Coon, C. N.: Developmental changes of plasma insulin, glucagon, insulin-like growth factors, thyroid hormones, and glucose concentrations in chick embryos and hatched chicks, Poultry Sci., 86, 673-683, 2007.

Molenaar, R., Van den Anker, I., Meijerhof, R., Kemp, B., and Van den Brand, H.: Effect of eggshell temperature and oxygen concentration during incubation on the developmental and physiological status of broiler hatchlings in the perinatal period, Poultry Sci., 90, 1257-1266, 2011.

McNabb, F. M. A.: Thyroids, in: Sturkie's Avian Physiology, 5th edn., edited by: Whittow, G. C., Academic Press, New York, 461-469, 2000.

McNabb, F. M. A. and Wilson, C. M.: Thyroid hormone deposition in avian eggs and effects on embryonic development, Am. Zool., 37, 553-560, 1997.

McWilliams, L. H.: Physiological impact of hematocrit level during stress in broilers, PhD thesis, Mississippi State University, USA, 2008.

Monge, C. and León-Velarde, F.: Physiological adaptation to high altitude: oxygen transport in mammals and birds, Physiol. Rev., 71, 1135-1172, 1991.

Mutoh, T., Sanosaka, T., Ito, K., and Nakashima, K.: Oxygen Levels Epigenetically Regulate Fate Switching of Neural Precursor Cells via Hypoxia-Inducible Factor $1 \alpha$-Notch Signal Interaction in the Developing Brain, Stem Cells, 30, 561-569, 2012.

Narushin, V. G.: Egg geometry calculation using the measurements of length and breadth, Poultry Sci., 84, 482-484, 2005.

Olkowski, A. A. and Classen, H. L.: Echocardiographic evaluation of heart function in normal chickens and chickens with heart failure and ascites, Poultry Sci., 78, Suppl. 1, Abstract 250, 1999.

Onagbesan, O., Bruggeman, V., De Smit, L., Debonne, M., Witters, A., Tona, K., and Decuypere, E.: Gas exchange during storage and incubation of avian eggs: effects on embryogenesis, hatchability, chick quality and post-hatch growth, World. Poultry Sci. J., 63, 557-573, 2007.

Ozaydin T. and Celik I.: Effects of high incubation temperature on the body weight and yolk consumption of two commercial broiler strain, Acta Sci. Vet., 42, 1253, 1-5, 2014.

Peebles, E. D. and Brake, J.: Eggshell quality and hatchability in broiler breeder eggs, Poultry Sci., 66, 596-604, 1987.

Peebles, E. D. and McDaniel, C. D.: A pratical manualfor understanding the shell structure of broiler hatching eggs and measure- 
ments of their quality, Office of Agricultural Communications, Mississippi, USA, Bulletin 1139, 1-16, 2004.

Perez-Perri, J. I., Acevedo, J. M., and Wappner, P.: Epigenetics: new questions on the response to hypoxia, Int. J. Mol. Sci., 12, 47054721, 2011.

Salinas, C. E., Blanco, C. E., Villena, M., and Giussani, D. A.: Highaltitude hypoxia and echocardiographic indices of pulmonary hypertension in male and female chickens at adulthood, Circ. J., 78, 1459-1464, 2014.

Sas Institute Inc: SAS for Windows Release, 8, NC, USA, 2007.

Scheele, C. W. and Frankenhuis, M. T.: Stimulation of the metabolic rate in broilers and the occurrence of metabolic disorders, in: Energy Metabolism of Farm Animals, edited by: Van der Honing, Y. and Close, W. H., European Association of Animal Production, 43, 251-255, 1989.

Semenza, G. L.: Targeting HIF-1 for cancer therapy, Nat. Rev. Cancer, 3, 721-732, 2003.

Simon, M. C. and Keith, B.: The role of oxygen availability in embryonic development and stem cell function, Nat. Rev. Mol. Cell Bio., 9, 285-296, 2008.

Tickle, P. G., Paxton, H., Rankin, J. W., Hutchinson, J. R., and Codd, J. R.: Anatomical and biomechanical traits of broiler chickens across ontogeny. Part I. Anatomy of the musculoskeletal respiratory apparatus and changes in organ size, PeerJ, 2, e432, https://doi.org/10.7717/peerj.432, 2014.

Tong, Q., Romanini, C. E., Exadaktylos, V., Bahr, C., Berckmans, D., Bergoug, H., and Demmers, T.: Embryonic development and the physiological factors that coordinate hatching in domestic chickens, Poultry Sci., 92, 620-628, 2013.
Tzschentke, B. and Nichelmann, M.: Development of avian thermoregulatory system during the early postnatal period: Development of the thermoregulatory set-point, Ornis Fennica, 76, 189198, 1999.

Wideman, R. F., Rhoads, D. D., Erf, G. F., and Anthony, N. B.: Pulmonary arterial hypertension (ascites syndrome) in broilers: a review, Poultry Sci., 92, 64-83, 2013.

Xia, X. and Kung, A. L.: Preferential binding of HIF-1 to transcriptionally active loci determines cell-type specific response to hypoxia, Genome Biol., 10, R113, https://doi.org/10.1186/gb2009-10-10-r113, 2009.

Xia, X., Lemieux, M. E., Li, W., Carroll, J. S., Brown, M., Liu, X. S., and Kung, A. L.: Integrative analysis of HIF binding and transactivation reveals its role in maintaining histone methylation homeostasis, P. Natl. Acad. Sci. USA, 106, 4260-4265, 2009.

Yalçın, S., Çabuk, M., Bruggeman, V., Babacanoğlu, E., Buyse, J., Decuypere, E., and Siegel, P. B.: Acclimation to heat during incubation. 1. Embryonic morphological traits, blood biochemistry, and hatching performance, Poultry Sci., 87, 1219-1228, 2008.

Zhang, H. and Burggren, W. W.: Hypoxic level and duration differentially affect embryonic organ system development of the chicken (Gallus gallus), Poultry Sci., 91, 3191-3201, 2012.

Zhang, H., Wang, X. T., Chamba, Y., Ling, Y., and Wu, C. X.: Influences of hypoxia on hatching performance in chickens with different genetic adaptation to high altitude, Poultry Sci., 87, 2112 2116, 2008. 